\title{
Chapter 3 \\ Pathways into Irregular Legal Status of Senegalese Migrants France, Italy, and Spain
}

\begin{abstract}
"Illegal" migration is a major concern in most immigrant-receiving countries, yet most policy and much research on the topic is hampered by a lack of data and a misunderstanding of the origins and trajectories of so-called undocumented migrants' legal statuses. Irregular migration is difficult to measure empirically, as it, by definition, escapes the detection of most states' immigration-control bureaucracies. In addition, many surveys have difficulty in sampling what is a mostly hidden population. This lack of data has undoubtedly contributed to an even bigger problem in the study of irregular migration: the conflation of undocumented border crossing with the broader phenomenon of irregularity of legal status. In reality, clandestine border crossing is but one pathway among many into irregular legal status and may not even be the most important one in many countries. Furthermore, immigration policies actively produce these pathways into irregularity through restrictive control mechanisms. A more thorough understanding of the implications of irregularity for both destination societies and for the migrants themselves must therefore study multiple pathways into irregular status.

An approach that is sensitive to the multiplicity of pathways and the role of immigration policies in producing them is especially crucial for understanding irregularity in European destinations. Restrictive immigration-control policies with an emphasis on border control have become the norm in Europe, yet the continent hosts an increasing population of irregular migrants and many countries embark on repeated regularization programs to adjust irregular migrants' legal status. The contradictions inherent in this system may stem from a misapprehension of the nature of irregular migration: research has shown that overstaying after legal entry may be a more important pathway to irregularity than illegal entry, and other policies may facilitate transitions to irregular status while the state pursues regularization programs.
\end{abstract}

The original version of this chapter was revised: Footnote was inserted in the chapter opening page. The correction to this chapter is available at https://doi.org/10.1007/978-3-030-12088-7_7

Portions of Chapter 3 were previously published as: Vickstrom, E. (2014). Pathways into irregular status among Senegalese migrants in Europe. International Migration Review, 48(4), 1062-1099. https://doi.org/10.1111/imre.12154. 
Migration from sub-Saharan Africa in particular has fallen victim to the confusion surrounding the multiplicity and legal production of irregularity. Highly mediatized arrivals of African migrants in leaky fishing boats on European shores in 2006 prompted fears of an "African invasion" and a flurry of restrictive measures to stop it, yet the image of Africans as clandestine migrants both hides the heterogeneity of African migrants' legal situations and obscures the role of European states' immigration policies in producing these situations.

This chapter will analyze the multiple pathways into irregular status for Senegalese migrants. It will argue that irregularity is "legally produced" by immigration policies and will advocate for a conceptualization of legal status that is context-dependent, multidimensional, and longitudinal. The empirical focus will be on the pathways of entry without a visa, overstaying following a legal entry, and "befallen irregularity," or transitioning from regular to irregular legal status. The chapter will analyze the administrative trajectories of Senegalese migrants in France, Italy, and Spain. As Chap. 2 demonstrated, these contexts of reception display variation both within and between countries and over time in their immigration-control mechanisms.

This chapter capitalizes on variation in the forms of irregularity and contexts of reception to ask the following questions: What are the correlates of each of these pathways for Senegalese migrants in France, Italy, and Spain? What role does context of reception play in shaping the pathways of irregularity? Are the pathways linked, i.e., to what extent is irregularity "sticky" or path dependent? Given the diversified profile of Senegalese migrants in these different destinations, what role do various forms of capital play in steering migrants into the various pathways of irregularity? Given the role of policies making regular status contingent on links to family or the formal labor market, what role do these social institutions in the destination country play in structuring these pathways?

The chapter is organized as follows. Section 3.1 reviews the literature on definitions and conceptualizations of migrant irregularity and outlines the empirical pathways into irregular status to be studied. Section 3.2 offers hypotheses: pathways will be structured by contextual variation, and migrants will navigate them with the help of access to forms of capital and links to other social institutions. Section 3.3 describes the data and methods. Section 3.4 presents the chapter's findings: context and forms of capital are more strongly related to pathways that occur more closely in time to the act of crossing a border, while changes in legal status are more closely related to links to social institutions and prior legal statuses. Section 3.5 discusses these results and Sect. 3.6 concludes.

\subsection{Conceptual Approaches to Irregularity}

In addition to these lexical nuances surrounding irregular migration described in Chap. 1, the concept of irregularity is plagued by lack of precision in its categorical and temporal dimensions. Figure 3.1 illustrates the common conceptual problems. Much media, policy, and even academic attention to "irregular" migration actually focuses solely on the legal domain of entry. This may be due in part to the influence 


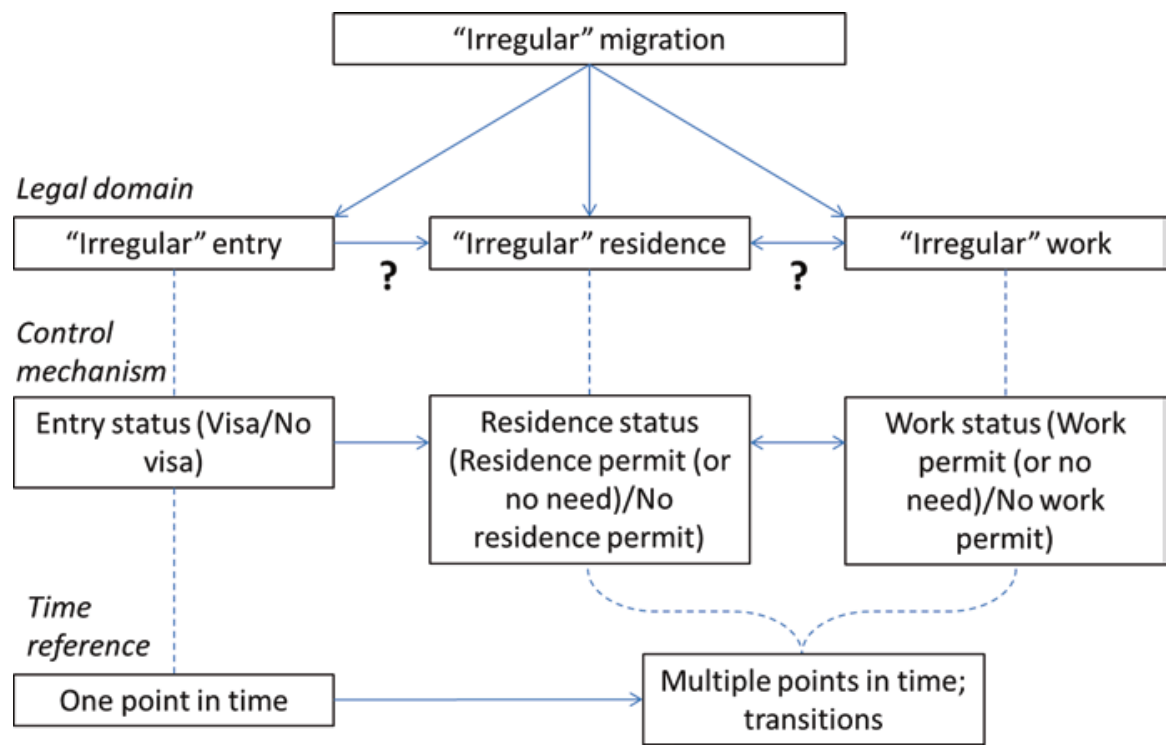

Fig. 3.1 Temporal and categorical complexity of irregularity of legal status

of the U.S. case on perceptions of migration: unauthorized border crossing dominates popular and academic discussions of irregularity in the U.S., and this concept is exported to other contexts. Thus, irregular entry comes to stand for irregular migration, and irregular migrants are those that entered without the required authorization.

In reality, as Fig. 3.1 illustrates, irregularity of legal status is both categorically and temporally more complex. Irregularity can arise not only from the legal domain of entry but also from the legal domains of residence and work; lack of authorization in any of these legal domains can generate irregular status. A proper understanding of irregularity thus must pay attention to multiple legal domains that give rise to categorical complexity of statuses, and also to the mechanisms of immigration control (e.g., documents such as visas and residence permits) that mark migrants as irregular (Brochmann 1999). Furthermore, these multiple legal domains introduce temporal complexity: while irregular entry is defined at one point in time, irregularity of residence and work authorizations is defined at multiple points in time during a migrant's trip. Irregularity as a concept must thus include multiple legal domains and multiple statuses over time.

The categorical and temporal complexity of irregularity illustrated in Fig. 3.1 demonstrates that there are multiple possible pathways into irregular status. Unlike the U.S. context, where irregular entry is the predominant pathway into irregular status, the European context displays a variety of pathways, including unauthorized entry, work in violation of residence conditions, refused asylum application, and irregularity by birth. In addition, "status flows," or transitions between various kinds of statuses are common and include overstaying and befallen irregularity (Düvell 2008, 2011b; Triandafyllidou 2010a). Furthermore, unauthorized border crossing, while it garners a fair share of public and policy attention in Europe, is far from the 
most common pathway into irregular status. Instead, research has shown that overstaying is by far the predominant pathway in most European countries (Finotelli and Sciortino 2013; Kraler 2009), underlining the need for a theoretical and analytical approach that accounts for transitions between legal statuses over time.

\subsubsection{The Legal and Social Production of Irregularity}

While the preceding discussion highlights the multidimensionality of irregularity and the multiple pathways by which migrants access irregular status, many sociological investigations of irregular migration rely on a simple dichotomy of legal status. This is especially true in the United States, and even though the American research tradition has produced useful findings regarding undocumented migration in the US context of reception (Alba and Nee 2003; Borjas and Tienda 1993; Kossoudji and Cobb-Clark 2000; Phillips and Massey 1999; Portes and Rumbaut 2001), scholars have recently begun to argue for more nuanced conceptualizations of irregularity. Research focusing on the social construction of legal-status categories allows both an understanding of how irregularity is produced by historical and sociolegal processes (De Genova 2002) and an expanded conceptualization of irregularity that includes both precarious categories and the dynamism of irregularity over time (Goldring et al. 2009).

Scholars researching the "legal production of illegality" (Goldring et al. 2009) have argued that the notion of irregularity is meaningless without reference to the legal framework in which it is defined: irregular status as a transgression is impossible without the legal framework defining it as such (Sciortino 2004). Research on the production of illegality has shed light on how the seemingly common-sense notion of migrant irregularity is embedded in concrete historical processes and institutions such as laws, policies, labor markets, and other social institutions in destination countries (Calavita 1998; De Genova 2002). Immigration-control policies dictate the channels of legal entry, residence, and work in the destination country and the bureaucratic mechanisms that regulate both these channels and access to other social institutions (such as health care, education, and the possibility of family reunification). These policies and their translation into concrete bureaucratic mechanisms of control (such as visas, residence permits, and work permits) thus set the parameters for the irregular statuses that migrants may experience and the pathways by which they access them. Irregular status thus entails a social relation to a state and its policies and control mechanisms, which themselves have a history within the political process of the state (Sciortino 2004).

Contextual variation is thus crucial in elucidating how different forms of irregularity emerge from different social, legal, and political configurations, especially in a policy context as turbulent as the one in Europe, where frequent changes in immigration legislation and policy are the norm. For example, Düvell (2011a) reports that at least 52 separate laws, codes, decrees, and circulars define French immigration law, and turnover in political leadership has led to 20 immigration laws being 
adopted since 1980 (Wihtol de Wenden 2010). While some of this turbulence in policy has accompanied the transposition of treaties or European Union directives into national laws (as was the case with major Italian and Spanish immigration legislation in the 1990s), individual countries have also fought to maintain sovereignty in much immigration policy making; consequently, there is no commonly accepted definition of irregularity across European countries (Düvell 2011a). This policy turbulence can change the parameters of regularity by making renewal of statuses more difficult or by revoking some forms of status altogether. As a result, migrants may experience categorically complex legal statuses (e.g., legal residence without legal right to work) along with complex trajectories of legal status over time arising from frequent transitions.

The in-depth review of the evolution of immigration policies in France, Italy, and Spain in Chap. 2 highlighted the turbulence of immigration policies in these three countries. Table 3.1 sketches these evolutions and illustrates how policy variation over time and across destinations variation in irregularity over time and across destinations creates different pathways of irregularity. As Chap. 2 showed, France, for example, established a preferential bilateral immigration control regime with Senegal that allowed for free circulation and establishment in each country for nationals of the other. While this was at heart an attempt to maintain French colonial privilege (Donovon 1988), it allowed Senegalese to enter, reside, and live in France without the need for explicit authorization (Marot 1995). Over time, France aligned its bilateral agreements with Senegal with the common immigration-control regime, thus creating irregularity among Senegalese migrants who had not previously been subject to restrictive policies (Lochak 1997).

Table 3.1 also highlights the important variation that exists between destinations at any historical moment. Whereas all three countries have experienced a general evolution towards restrictive immigration-control policies, the features and timing of these policies have not been uniform. France's stiffening of immigration control, for example, occurred at the same time that the southern European countries were dealing with growing foreign-born populations via regularization programs, which may have created new pathways of irregularity in all countries.

The literature on the legal production of irregularity also highlights the role that other social institutions play, either independently or in interaction with immigrationcontrol policies, in creating forms of irregularity. Social institutions are symbolic blueprints that organize people's roles in major areas social life, including the polity and the economy (Portes 2010). In addition to the state's immigration-control apparatuses, social institutions such as the work and the family are likely to have impacts on migrants' legal statuses. State immigration control policies can obviously regulate access to the formal labor market, but the existence of widespread informal employment opportunities may make it easier for migrants to circumvent formal mechanisms of control (Reyneri 1998); the structure of the labor market is thus another contextual factor that can influence the pathways of irregularity. Other social institutions in the destination society can also help create frameworks for irregularity: the ability of migrants with irregular status to access health care and educational systems may make some forms of family irregularity more likely. This 


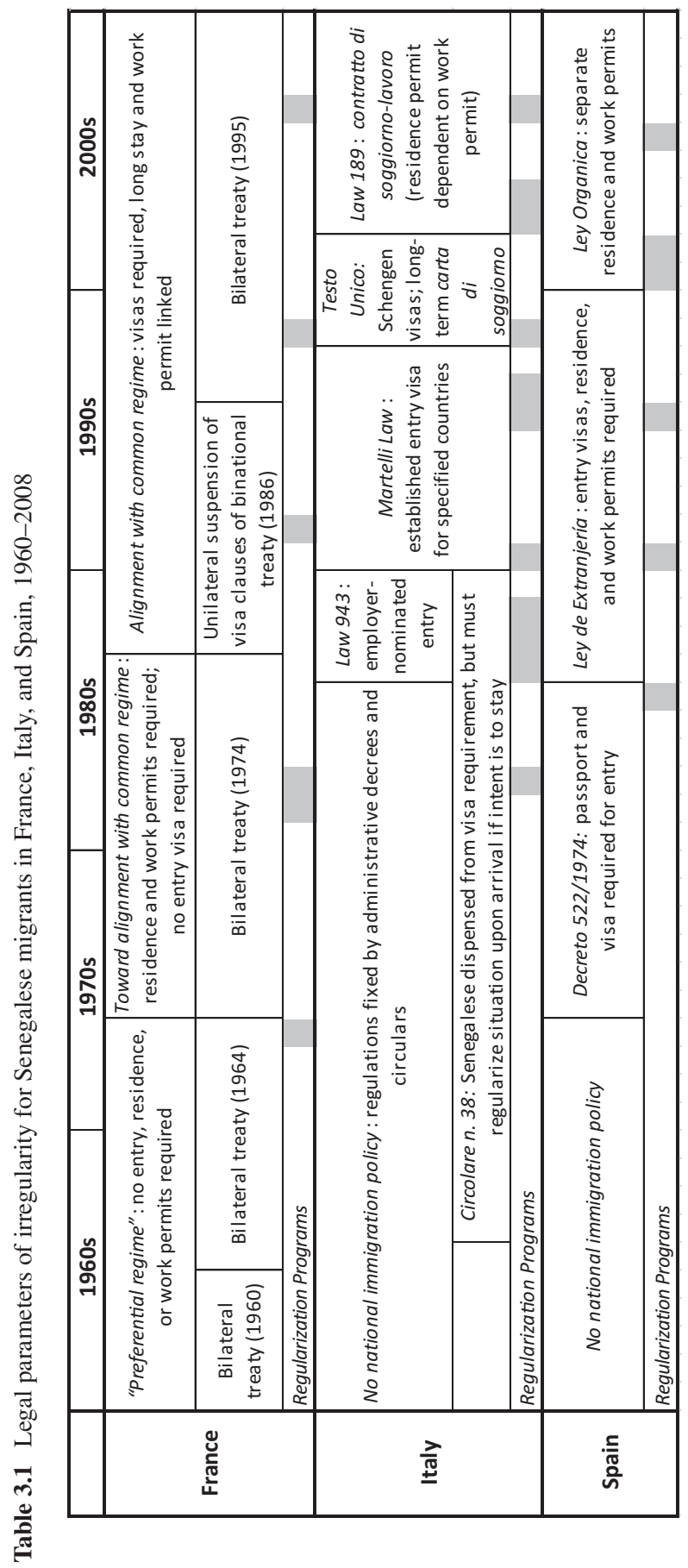


has been suggested in the Spanish case, where legal protection of social rights for migrants with irregular status has made irregular residence and work less risky (González-Enríquez 2009; González-Ferrer 2011a). The social institution of the family itself may also shape pathways of irregularity. Some contexts might promote irregular forms of reunification of family members of migrants, as in Spain where waiting periods imposed on work authorizations for reunified spouses may incentivize bypassing legal reunification channels (González-Ferrer 2011b). Still other policy regimes might facilitate accessing regular status on the basis of "entitlements" in immigration legislation (Kraler 2009) such as familial links, as is the case for parents of minor children born in France since the passage of the Chevènement law in 1998 (Lessault and Beauchemin 2009).

\subsubsection{Multidimensionality of Irregularity}

It is clear from the literature that policies and institutions in the destination society constitute a legal and social framework for the pathways of irregularity. The literature also emphasizes that these frameworks create the conditions for a multiplicity of forms of irregular status, and thus responds to a call for research that acknowledges a continuum of legal statuses and studies transitions between different kinds of legal status (Coutin 1998; Massey and Capoferro 2004; Menjívar 2006).

In disaggregating binary oppositions of regular/irregular status (Donato and Armenta 2011), research has shown that there are a multitude of "precarious" or "liminal" statuses in between the two poles of documented and undocumented and a variety of pathways into these statuses (Düvell 2008; Goldring et al. 2009; Menjivar 2006). Much of this research has focused on non-US contexts of reception where undocumented border crossing is not the only, or even the most important, pathway to irregularity. Goldring et al. (2009, Goldring and Landolt 2011), for example, propose the concept of "precarious legal status," which highlights the multiple forms of impermanent and insecure status that migrants in Canada face. They find that Canadian immigration policy offers several avenues for authorized entry and that migrants often become irregular by losing this authorization once in the country. Their research has also examined transitions between legal statuses and suggests that some pathways of irregularity are more difficult to escape than others (Goldring and Landolt 2011). Canadian immigration-control policy thus produces multiple pathways into irregularity via a multiplicity of precarious statuses. This research echoes findings in other contexts of reception, particularly those of southern Europe where "irregularizing" policies are the norm (Calavita 1998; Schuster 2005).

Other studies offer different typologies but retain the emphasis on complex and multidimensional trajectories of legal status that reflect the contextual specificities of different destinations. Kraler (2009) outlines 13 different "dimensions of illegality" stemming from lack of entry, residence, or work authorization across countries of the European Union. Jandl (2004) employs distinctions between entry, residence, 
and work to generate a typology that includes six categories of clandestine existence and argues that no accurate accounting of illegal migrant flows and stocks can occur without such a fine-grained conceptualization. Ruhs and Anderson (2010) distinguish between compliance, semi-compliance, and non-compliance in examining the labor-market participation of immigrants in the United Kingdom. These studies illustrate that authorizations in different legal domains can combine to create mixed, precarious, semi-irregular, or in-between statuses and that migrants can experience transitions over time between a variety statuses (Düvell 2011a, b). Instead of a bright, stable boundary between regular and irregular status, there is a fuzzy threshold that shifts over time. The categorical multidimensionality and temporal instability of irregular statuses allow an examination of multiple pathways into irregularity over the course of migrants' trajectories.

\subsubsection{Incomplete State Control and Migrant Agency}

This expanded conceptualization of irregularity that is both dynamic and contingent on contextual factors such as legal frameworks and policies allows a more refined understanding of how irregularity is produced. At the same time, much recent research has also insisted on migrants' agency in navigating the laws and policies that set the parameters of their legal statuses. As Sciortino (2004) points out, state claims of control of immigration are never complete: strong policies can fail when the social infrastructure of immigration is robust enough to offer migrants ways of circumventing control mechanisms. This social infrastructure includes individual and collective resources, such as financial, human, social and migration-specific capital (Massey and Espinosa 1997). Research has shown access to these resources to be important at many points in the migration process, including the mode of migration and the legal integration into the destination society (Massey et al. 1998; Massey and Espinosa 1997; Portes and Rumbaut 2006; Singer and Massey 1998).

Migrants can draw on different kinds of resources in their interactions with legal institutions and bureaucracies to influence the process of categorization and documentation. Coutin (1998) argues that migrants, far from being passive in the face of immigration laws and policies, actively interpret and react to such contextual constraints. This engagement allows migrants not only to shape their own legal identities but also to influence the very legal categories that the law presents to them. Spire (2005) demonstrates this agency via the "paper careers" of foreigners in France: migrants were often able to influence their own statuses as a result of bureaucratic agents' institutional autonomy vis-à-vis immigration legislation. Mass movements of migrants can also use political capital to feed back into the policy process and create new legal categories: the sans papiers movement in France in the 1990s at least partially succeeded in forcing legislators to create a legal solution for migrants who were neither regularizable nor deportable (Lochak 1997). While these studies have emphasized the role of forms of capital in accessing regular legal 
status, Sciortino (2004) argues that access to resources is also a precondition to irregular migration, which is an inherently risky and expensive endeavor.

\subsubsection{Pathways into Irregularity}

These conceptual approaches to the production of multidimensional forms of irregularity make the case for important heterogeneity hidden by a binary conceptualization of irregularity, but they also lend themselves to a potentially unending array of typologies of different kinds of legal statuses. This chapter draws on this literature to examine a limited set of three concrete pathways into irregularity for empirical examination. This section reviews the pathways of no-visa ("irregular") entry, overstaying, and befallen irregularity. The discussion will focus on the concrete policy mechanisms of control that define each pathway and the evolution of these control mechanisms in France, Italy, and Spain, both in general and vis-à-vis Senegalese migrants in particular.

\section{Geographic Flows into Irregularity and Mechanisms of External Control: No-Visa Entry}

Entering a country without the proper documentation is a "geographic flow" (Triandafyllidou 2010a) into irregular status: migrants move from one place and enter another without the proper authorization or documentation. While research in the European context has shown that this pathway to irregular status is more limited in its extent than in the US, European countries have invested in restrictive border control and their political discourses around irregular migration focus heavily on undocumented entry (Vollmer 2011).

The main mechanism of control regulating the pathway of irregular entry is the entry visa. In France, visas were nominally required for entry by the 1945 ordinance that organized post-war immigration, but French external control policy was porous until the 1980s. This was particularly true for Senegalese: as a result of a series of bilateral agreements that defined the conditions of entry, residence, and work for Senegalese in France and took precedence over national immigration legislation, Senegalese citizens did not need a visa to enter France between 1960 and 1986 (Marot 1995; Mezger and González-Ferrer 2013). As part of an effort to "close the borders" following economic crises in the 1970s (Lochak 1997), France unilaterally declared entry visas necessary for all non-EU foreigners, including Senegalese, in a governmental circular in 1986 (refer to Chap. 2 for additional details on the evolution of this mechanism of control).

While French policy subsequently lifted visa requirements for nationals of EU and other developed countries, foreigners from many less-developed countries, including Senegal, are still required to have visas to enter France. Despite this evolution towards increased external control, including increased border policing and 
stricter guideline for visa issuance, there are no widely accepted estimates of the number or characteristics of irregular entries to France (Courau 2009). Some research suggests, however, that migrants from France's Mediterranean neighbors (Egypt, Tunisia, Morocco, and Algeria) and former colonies (Senegal, Mali, and Mauritania) are more likely to enter with falsified documents (Wihtol de Wenden 2010).

Irregular entry has long been perceived by northern Europeans to be a more pressing problem in southern Europe, particularly in Italy and Spain. Indeed, both countries are infamous for images of clandestine migrants arriving by boat from the coasts of North or West Africa (Fasani 2010; González-Enríquez 2009, 2010; Pastore et al. 2006) and only developed national-level immigration legislation in the 1980s in response to pressure from other Schengen and EU members concerned about these porous Mediterranean borders. Spain, while having previously established visa requirements via administrative circular or royal decree, instituted Schengen-style visa requirements in an organic law in 1985. Italy allowed Senegalese nationals to enter the country without a visa between 1966 and 1990 (Mezger and González-Ferrer 2013), but abolished this provision in 1990 as part of a general reform of entry policy in accordance with Schengen regulations.

These visa requirements have been part of a general evolution in both southern European countries towards stiffer external controls to combat the perceived threat of irregular entries (Finotelli and Sciortino 2009; González-Enríquez 2009; Sciortino 1999). In reality, unauthorized geographic inflows represent a small proportion of irregular residents in Italy: Fasani (2010) estimates that as few as $4 \%$ of irregular migrants entered without authorization by sea, and as few as $15 \%$ by airport or land borders. Irregular entry to Spain was a significant pathway to irregularity in the 1990s with many clandestine migrants arriving in boats from Morocco, but this pathway has decreased in significance with increased high-tech surveillance of coastlines and bilateral readmission agreements with origin and transit countries (González-Enríquez 2010).

\section{Status Flows into Irregularity and Mechanisms of Internal Control: Overstaying and Befallen Irregularity}

In contrast to geographic flows, status flows involve migrants who are already in a destination country and change legal status (Triandafyllidou 2010a). Status flows towards irregularity can involve overstaying a tourist visa and becoming irregular with regard to work and/or residence; or losing regular residence/work status during a stay in a destination country (otherwise known as "befallen irregularity"). Residence and work permits, which define a foreigner's authorization to reside and work in a destination country, are the main mechanisms of internal control in France, Italy, and Spain; these permits thus define these status-flow pathways of irregularity. Research on irregularity in Europe has demonstrated that status flows are by far the predominant pathway into irregular status (Triandafyllidou 2010a). 
Overstaying — legal entry (with or without a visa and usually for tourism) followed by remaining in the country after the expiration of the visa or entry authorization-represents the most prevalent pathway to irregularity in Europe, and is common in all three countries in this study (Düvell 2011b; Finotelli and Sciortino 2013; Sciortino 2004). While this pathway is often referred to as "visa overstaying," there are many cases in which migrants can be authorized to enter a destination without a formal visa.

In France, many overstayers enter with visas for tourism, studies, family visits, or business and become irregular once their visa/entry authorization has expired and they stay in the country without a valid residence permit (Courau 2009; Wihtol de Wenden 2010). As many of these entry visas are issued under the Schengen rules, they are courte durée (short duration): they allow for a stay in France of only 3 months and do not allow the holder to apply for a residence permit (GISTI 2011). The preferential bilateral regime between France and Senegal also created conditions for overstaying. While Senegalese did not need visas to enter France prior to 1986, "false tourism" was a common strategy for migrating to France: obtaining a work contract in Senegal prior to departing for France was difficult, so many Senegalese entered France without a visa as ostensible tourists and subsequently found work (Bergues 1973). This can only be considered overstaying after 1974, though, which was when France first started requiring Senegalese to obtain residence permits after arrival.

Overstayers are also numerous in Italy: according to the Italian Ministry of Internal Affairs, upwards of $70 \%$ of irregular migrants in Italy between 2000 and 2006 became irregular by overstaying legitimate visas (Fasani 2010). Even though Senegalese migrants were exempt from visa requirements from 1966 to 1990, they were expected to regularize their status after arrival (Mezger and González-Ferrer 2013), leaving them open to irregular status after authorized (although not formally documented) entry. Subsequent Italian immigration laws specified that foreigners had to apply for residence permits within 90 days of arrival, but also made obtaining a residence permit dependent on having a work contract. Those migrants entering on tourist visas thus had little recourse to legitimate regular status once in Italy.

In Spain, overstaying is the main pathway to irregular status, with "false tourism" particularly common for migrants from Spain's former Latin American colonies (González-Enríquez 2010). As in Italy, secure residence status has been linked to employment, but a toleration of irregular work and the provision of some government benefits to irregular migrants has made it possible for migrants to overstay tourist visas (González-Enríquez 2010).

"Befallen irregularity" refers to a situation where migrants lose regular authorization for residence and/or work in a destination and thus fall into irregularity (Triandafyllidou 2010b). In general, this pathway is linked to immigration policies that define residence and work permits of limited duration in an effort to limit legal migration; the expiration of these permits without renewal leads to irregular status. Migrants may not be able to renew their permits for many reasons, but the most frequent obstacle they face is the fact that renewal of residence permits is often linked to proof of legal employment (Triandafyllidou 2010b). Loss of regular status 
may also, seemingly paradoxically, be linked to amnesty or regularization programs through similar employment provisions: migrants who temporarily gain legal status may fall into irregularity if they are unable to fulfill the employment conditions for renewal (Triandafyllidou 2010b). There is also evidence that bureaucratic inefficiencies in processing renewal application can lead to befallen irregularity (Düvell 2011b; Kraler 2009).

Befallen irregularity is a distinct risk for Senegalese migrants under the immigration laws in France, Italy, and Spain. Loss of regular status in France is linked to the limited duration of residence and work permits: most migrants with regular status possess a temporary permit with a maximum duration of 1 year, and they must apply for renewals while still in regular status; a permanent resident permit is only obtainable after years ${ }^{1}$ of continuous regular residence in France (GISTI 2011). Frequent changes in immigration law have been common and tightened renewal procedures have increased the risk of losing regular status (Lochak 1997). The experience of Senegalese sans papiers in France in the 1990s illustrated this risk: the Pasqua law of 1993 made renewal of permanent residence permits more difficult, thus creating many irregular migrants who were nonetheless not deportable because of family ties to France (Lochak 1997).

In Italy, legal employment is a prerequisite for legal residency, thus migrants who are unemployed or who are working in the underground economy can easily fall into fully irregular status because of lack of a formal work contract (Fasani 2010). Spain's approach to dealing with befallen irregularity has evolved over time: prior to 2000, migrants could lose regular status because of bureaucratic delays, but the immigration laws of that year specified that non-response by the administration 3 months after the submission of a renewal application constitutes a renewal of regular status (González-Enríquez 2010). Still, Spain has similar employment provisions to Italy, and many migrants thus lose regular status when they are unable to prove legal employment; this is especially true following extraordinary regularizations, the requirements of which are less strict than for subsequent renewals (González-Enríquez 2010). These inconsistencies in Spanish immigration law have led scholars to conclude that maintaining regular status is almost impossible in Spain (Calavita 1998; Donato and Armenta 2011).

\subsection{Hypotheses}

The geographic and status flows discussed above represent the most important pathways - in either numeric or political terms - into or out of irregular status in France, Italy, and Spain. These pathways are ideal types, and the goal of this chapter is to determine how Senegalese migrants in the main contexts of reception in Europe

\footnotetext{
${ }^{1}$ The required waiting period has varied over time and is currently 5 years (GISTI 2011).
} 
navigate these pathways. The theoretical literature reviewed above offers several hypotheses regarding variation in pathways of irregularity:

Legal and Social Production of Irregularity Variation in immigration-control policies and related social institutions over destinations and time will produce variation in the pathways of irregularity for Senegalese migrants in France, Italy, and Spain.

- Pathways of irregularity will be positively associated with more-recent periods as restrictive immigration-control policies create more pathways to irregular status;

- Migrants in Italy and Spain will experience more forms of irregularity as a result of contextual factors such as later establishment of restrictive immigration policy, longer borders with migrant-sending regions, and greater social tolerance of irregularity;

- Links to other institutions: unemployment may lead to increased risk of irregular status because the renewal of permits is often linked to having a formal work contract, especially in Spain and Italy; spousal or parental connections in the destination country may be associated with decreased probability of experiencing irregular pathways because of provisions that grant legal status for family reunification, being the parent of a minor child, or marrying a citizen of the destination country.

Migrant Capital and Strategic Action Migrants' access to different forms of capital will influence their navigation of pathways of irregularity. In particular, migrants with greater access to human, financial, and social capital will be less likely to experience irregularity, but some forms of migration-specific capital (e.g., previous irregular experience) may increase the probability of other forms of irregularity.

Linkages Between Pathways of Irregularity Forms of irregularity can be temporally interrelated and difficult to escape, and can also provide migrants with skills and knowledge that make subsequent circumvention of immigration-control mechanisms more likely.

\subsection{Data and Methods}

\subsubsection{Sample}

This chapter uses longitudinal life-history data from the Migrations between Africa and Europe (MAFE)-Senegal project, described in detail in Chap. 1. The project collected retrospective data that included complete year-by-year residential and administrative histories of each respondent, along with a host of other sociodemographic data (for more information on MAFE-Senegal methodology, see Beauchemin 2012, 2018). 
The sample for the analysis in this chapter includes individuals who have migrated at least once to Italy, France or Spain while they were greater than 18 (see Chap. 1 for more details on the MAFE sampling and selection scheme). Returned migrants interviewed in Senegal are included if they spent at least a year in at least one of the destination countries. Approximately $14 \%$ of the migrants spent time in multiple destinations within the three main contexts of reception; this chapter considers migration "spells" or individual trips of 1 year or greater by grouping the years that an individual migrant spent in an individual country. This yielded 768 individual- and destination-specific trips that form the basic unit of analysis: 305 in France, 239 in Italy, and 224 in Spain. Descriptive statistics for this sample by country of destination, calculated with probability sampling weights, are available in Table 3.2. These descriptive statistics show important differences between Senegalese migrants in the different contexts of reception. Men account for more than $80 \%$ of the person-years spent by Senegalese migrants in Italy and Spain, but only 59\% in France. Human capital varied across destinations: Senegalese migrants in France tend to be more highly educated with an average of 11 years of formal schooling, compared to 9.8 years in Italy and 6.7 in Spain. More than half of Senegalese migrants in Spain (63\%) and Italy (56\%) reported not speaking the hostcountry language before arrival, while proficiency in French was almost universal prior to arrival in France. Contexts of reception also varied: almost half of migrants in France arrived before 1990, while most in Italy (48\%) and Spain (66\%) arrived after 2000 .

\subsubsection{Legal Status Variables}

Administrative histories provided information on migrants' statuses in the legal domains of entry, residence, and work authorization. Table 3.3 provides the wording of the questions that elicited these statuses and the coding of responses. A dichotomous variable captures entry status as visa $(\mathrm{V})$ or no visa $(\mathrm{NV})$ based on migrants' responses about whether or not they had a visa when they entered the destination country; this variable is thus defined for the year of arrival for each trip. Senegalese nationals did not need visas to enter France between 1960 and 1985 or Italy between 1966 and 1990; migrants who entered those countries during those periods are coded as having a visa since they effectively had an authorized entry status.

For residence and work permits, the questionnaire asked about migrants' authorization in each year in a given destination, and allowed migrants to respond that they had, did not have, or did not need a permit; migrants were additionally able to specify if the work permit was "selective" (i.e., a permit limited to a specific activity). A dichotomous residence authorization variable captures residence permit (RP) or no residence permit (NRP) for each year in the trip, with those migrants who declared not needing a residence permit coded as having authorized residence status (RP) because of their effectively authorized status. A dichotomous variable for work status results in statuses of having/not needing a work permit (WP) and not having 


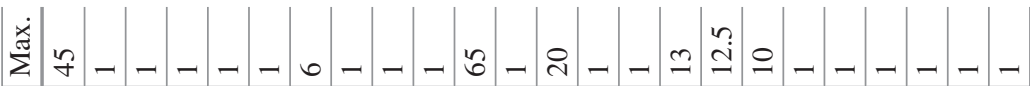
$\dot{\text { g }}$ $\Sigma-00000-000 \ln 000000-000000$

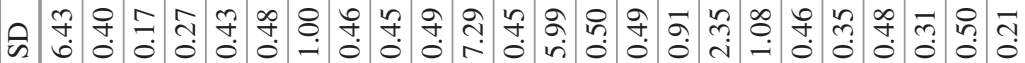

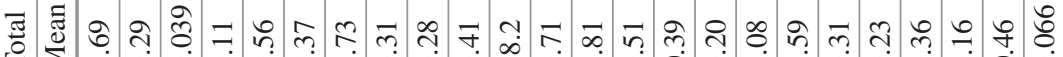

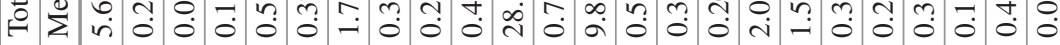

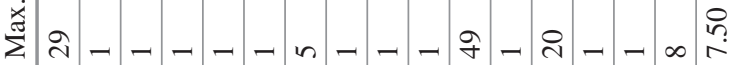

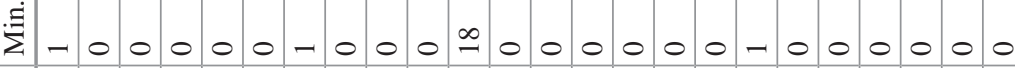

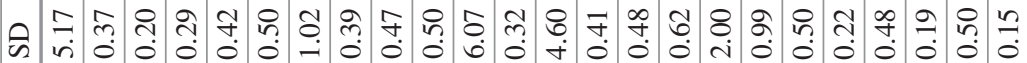

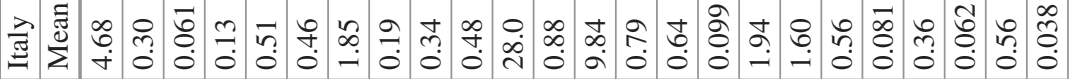

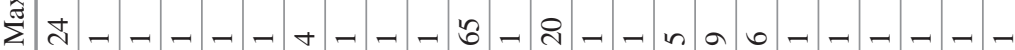
$\sum-00000-00017000000-000000$

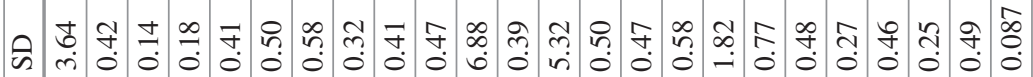

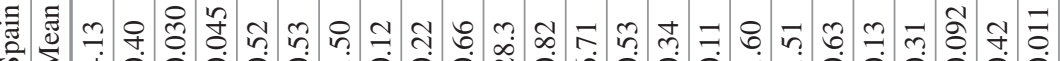

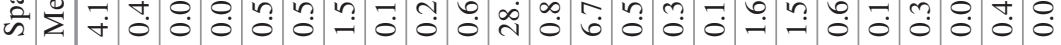

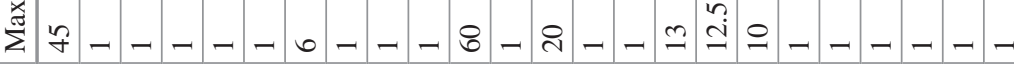

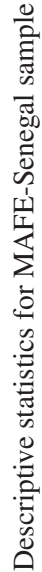
$\dot{\xi}$ $-00000-000$ n $000000-000000$ 诲의 की

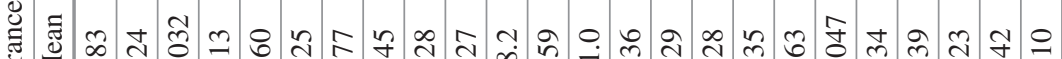

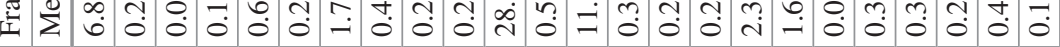

๗ั)

$\frac{2}{\sqrt{2}}$

20 की

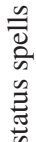

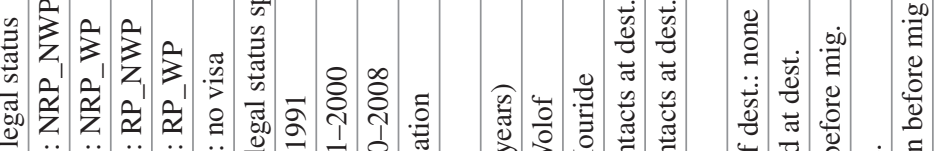
荌

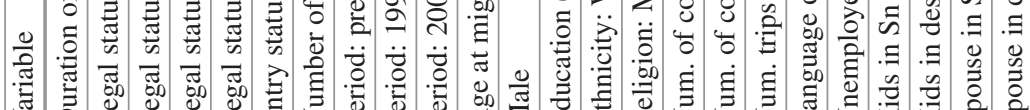
خ 


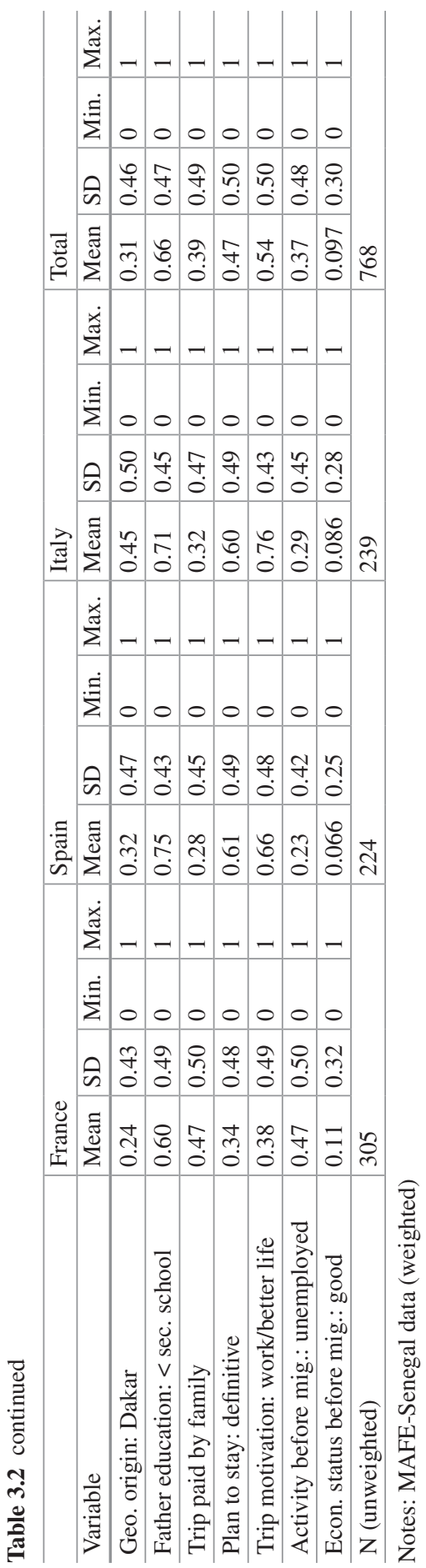


Table 3.3 Legal-status variables and coding, MAFE-Senegal survey

\begin{tabular}{|c|c|c|c|}
\hline $\begin{array}{l}\text { Legal } \\
\text { domain }\end{array}$ & Question & Modalities & Codes \\
\hline \multirow[t]{2}{*}{ Entry } & \multirow{2}{*}{$\begin{array}{l}\text { "When you arrived in [destination } \\
\text { country], did you have a visa? And then? } \\
\text { Did your situation change?" }\end{array}$} & Yes & V: Visa \\
\hline & & No & NV: No visa \\
\hline \multirow[t]{3}{*}{ Residence } & \multirow{3}{*}{$\begin{array}{l}\text { "When you arrived in [destination } \\
\text { country], did you have a residence permit? } \\
\text { And then? Did your situation change?" }\end{array}$} & Yes & \multirow{2}{*}{$\begin{array}{l}\text { RP: Residence permit/ } \\
\text { Did not need }\end{array}$} \\
\hline & & $\begin{array}{l}\text { Did not } \\
\text { need }\end{array}$ & \\
\hline & & No & $\begin{array}{l}\text { NRP: No residence } \\
\text { permit }\end{array}$ \\
\hline \multirow[t]{3}{*}{ Work } & \multirow{3}{*}{$\begin{array}{l}\text { "As for work, when you arrived in } \\
\text { [destination country], did you have a work } \\
\text { permit? And then? Did your situation } \\
\text { change?" }\end{array}$} & Yes & \multirow{2}{*}{$\begin{array}{l}\text { WP: Work permit/special } \\
\text { work permit/did not need } \\
\text { a work permit }\end{array}$} \\
\hline & & $\begin{array}{l}\text { Did not } \\
\text { need }\end{array}$ & \\
\hline & & No & NWP: No work permit \\
\hline
\end{tabular}

a work permit (NWP) for each year in the trip; those migrants who declared a selective work permit were collapsed into the work permit (WP) category.

A composite categorical variable for legal status in each year in the trip combines the indicators of residence and work permits. The combinations of these two forms of authorization were coded as: RP_WP (ego has both residence and work permits), NRP_WP (ego has no residence permit, but a work permit), RP_NWP (ego has a residence permit but no work permit), NRP_NWP (ego has neither a residence permit nor a work permit). This chapter will refer the RP_WP status as "fully regular," while NRP_NWP status is "fully irregular." This chapter uses a variety of terms to describe RP_NWP and NRP_WP statuses, including "precarious," "semicompliant," "semi-irregular," and "mixed." These indicators of legal status serve as both dependent and independent variables reflecting the pathways into irregularity under examination. This basic typology will serve as the main framework for legal status in this and subsequent chapters. The descriptive statistics in Table 3.2 show that migrants experience a variety of post-entry legal statuses, and that these statuses vary by destination. Migrants spend 56\% percent of their person years in fully regular (RP_WP) status across all destinations, and 29\% of their person years in fully irregular (NRP_NRP) status. They spend about $15 \%$ of person-years in semiirregular statuses, with lack of work authorization (RP_NWP) the most common precarious status. Migrants in France are most likely to have both a residence and a work permit (60\% of person-years), while migrants in Spain are most likely to have fully irregular status ( $40 \%$ of person-years). Both kinds of precarious status are more prevalent in Italy than in other destinations. While these descriptive statistics are once again suggestive of systematic differences in irregularity by context, they do not allow examination of disaggregated pathways. 


\subsubsection{Predictor Variables}

The main predictors of interest in the model are indicators of legal and social contexts of reception. Called contextual variables below, these include indicators for destination country (France, Italy, or Spain, with France serving as the reference category), period of arrival (prior to 1991, 1991-1999, and after 2000), and an indicator for whether or not a regularization program took place in the destination in the migrant's year of entry (see Kraler 2009: 37-39 for a comprehensive list of regularization programs).

The second set of predictors indicates a migrant's access to various forms of capital. Migration-specific capital or prior migration experience varies by model and includes prior no-visa entry and previous legal-status category. Human capital includes years of education and competence in the language of the destination. Financial capital includes participation of the family in financing the migration and the migrant's subjective economic status before migration. Social capital is captured by the number of contacts the migrant reports knowing at the destination prior (either prior to arrival or during the year of the outcome, depending on the model).

The third set of predictors captures a migrant's links to social institutions. Dummy variables indicate if the migrant has a spouse or children in the destination country, and a categorical variable indicates the migrant's labor-market status (working, unemployed, or inactive).

Models also include variables capturing individual sociodemographic characteristics, including age at migration and dummy variables for sex (male), ethnicity (Wolof), religion (Mouride), geographic origin in Senegal (Dakar), father's level of education (less than secondary school), migration plans (definitive stay), and migration motivation (work/better life).

\subsubsection{Models}

I model each of the three main pathways into irregular status reviewed above. The model for no-visa entry examines determinants of the dichotomous indicator for starting a trip with a visa and is thus a cross-sectional model at the time of arrival. The model for overstaying uses a cross-sectional multinomial logistic regression to study migrants' residence and work authorizations during the first year of residence in a destination. A final model for befallen irregularity examines transitions over time into fully irregular status and uses discrete-time survival methods. 


\section{No-Visa Entry}

For the model of the pathway of no-visa entry, the dependent variable is the dichotomous variable that indicates whether or not the migrant declared having a visa at the time of entry into the destination country, with values of 1 corresponding to "no visa" and values of 0 corresponding to "visa." All 768 trips and their entry-status indicators are included in the analytic sample for this model. I estimated the following cross-sectional logistic regression:

$$
\ln \left(\frac{\operatorname{Pr}(\text { NoVisa })}{1-\operatorname{Pr}(\text { NoVisa })}\right)=\alpha+X_{1} \beta_{1}+X_{2} \beta_{2}+X_{3} \beta_{3}+X_{4} \beta_{4}+X_{5} \beta_{5}
$$

where $\boldsymbol{X}_{1}$ is a vector of contextual variables, including an interaction between destination and period. $\boldsymbol{X}_{2}$ is a vector of variables indicating prior migration experience: a categorical variable encodes a previous migration spell beginning with or without a visa (with no previous migration spell as the reference category), and a dummy variable indicates whether ego was a returned migrant at the time of the survey. $\boldsymbol{X}_{3}$ is a vector of variables indicating access to forms of capital, with subjective economic status and number of contacts measured before the trip. $\boldsymbol{X}_{\mathbf{4}}$ is a vector of variables representing links to institutions, with employment measured in the year prior to the trip. $\boldsymbol{X}_{\mathbf{5}}$ is a vector of individual variables.

\section{Overstaying}

The analytic sample for the model of the pathway of overstaying again included all 768 trips. The dependent variable is the categorical variable indicating a migrant's legal status (combining indicators of residence and work authorization) during the year of arrival. I estimated the following multinomial logistic regression:

$\ln \left(\frac{\operatorname{Pr}\left(\text { Legal Status }_{i t 1}=i\right)}{\operatorname{Pr}\left(\text { Legal Status }_{t 1}=N R P_{-} N W P\right)}\right)=\alpha+X_{1} \beta_{1}+X_{2} \beta_{2}+X_{3} \beta_{3}+X_{4} \beta_{4}+X_{5} \beta_{5}$

where $i$ indexes the following values of the categorical legal-status variable for the first year at a destination: RP_WP (1), RP_NWP (2), NRP_WP (3); the reference category for this regression is NWP_NWP (4). Predictors are identical to those for Eq. (3.1), with the following exceptions: $\boldsymbol{X}_{2}$ is a dichotomous indicator of entry status during the same trip, coded as " 1 " for entry with a visa and " 0 " for entry without a visa; $\boldsymbol{X}_{\mathbf{3}}$ includes the number of previous migration spells as an indicator of migration-specific capital and measures self-reported economic status during year 1 of the migration spell; and the labor-market indicators in $\boldsymbol{X}_{\mathbf{4}}$ are measured during year 1 of the migration spell. Overstaying is indicated in this model by having entered with a visa and subsequently having a fully irregular legal status during the first year of residence at the destination. 


\section{Befallen Irregularity}

Befallen irregularity is indicated in this model by a transition into fully irregular (NRP_NWP) status. As a dynamic model, it follows individuals over the course of their stay in a destination until they fall into irregular status or are censored. The analytic sample for the model thus includes only those person-years during which a migrant had a fully regular status or a semi-irregular status (i.e., not NRP_NWP). This risk set thus includes 6731 person years. The outcome is a leading dichotomous variable indicating whether the migrant's legal status at time $t+1$ changed to fully irregular (NRP_NWP). I estimated a discrete-time survival model to study the probability of transition to irregular status:

$\ln \left(\frac{\operatorname{Pr}\left(N R P_{-} N W P_{t+1}\right)}{1-\operatorname{Pr}\left(N R P_{-} N W P_{t+1}\right)}\right)=\alpha+X_{1 t} \beta_{1}+X_{2 t} \beta_{2}+X_{3 t} \beta_{3}+X_{4 t} \beta_{4}+X_{5 t} \beta_{5}+X_{6 t} \beta_{6}$

where predictors are the same as in Eq. (3.2), except that $\boldsymbol{X}_{\mathbf{3}}$ now contains a trichotomous variable indicating ego's legal status at time $t$, which can take the values of RP_WP, NRP_WP, or RP_NWP. In addition, variables that are time-varyingnumber of contacts at the same destination, presence of family members at the same destination, and labor-market participation-are measured at time $t$ (a lag of -1 compared to the outcome variable).

\section{Estimation and Presentation of Models}

All models correct standard errors for clustering at the level of the individual, which allows the inclusion of multiple trips per individual. The results of the nonlinear multivariate models are in the form of average marginal effects. In ordinary least squares (OLS) models, regression coefficients represent marginal effects, or the expected change in the outcome variable for a one-unit change in the predictor variable. For nonlinear models, however, the use of a transformation that allows linear modeling of the dependent variable renders interpretation of coefficients less straightforward as the probability of the modeled outcome depends, in part, on the values of the predictors.

While some studies present results for nonlinear models as log-odds or odds ratios, presentation on the same scale as the original data, as is the case with marginal (also called partial) effects, is arguably easier to interpret. For example, computation of marginal effects after a logistic regression model would show how the probability of the outcome changes with a one-unit change for a given predictor variable. Marginal effects also allow for interpretable summaries of interactions between predictors that would be difficult to construct with odds ratios. Average marginal effects are calculated by computing a marginal effect for each case and averaging the value over all cases. If predictors are categorical, the AME represents the expected change in the outcome with a discrete change in the value of the categorical variable (see 
Cameron and Trivedi 2010 for more information on average marginal effects). Standard errors for AMEs are calculated using the delta method. Tables of untransformed coefficient estimates are available in this chapter's Appendix.

\subsection{Results}

\subsubsection{No-Visa Entry}

Descriptive statistics suggest initial support for the hypothesis that context of reception plays an important role in shaping the pathway of no-visa entry. Table 3.2 presents descriptive statistics for the sample under study and shows that $37 \%$ of the migration spells of Senegalese migrants in the MAFE sample started without a visa across all three destination countries. The probability of no-visa entry varies a great deal by destination: while only $25 \%$ of migration spells in France started without a visa, $46 \%$ did so in Italy and more than half (53\%) did so in Spain. Figure 3.2 shows further variation by destination and period. Across all three countries, the probability of no-visa entry has increased since the beginning of the 1990s. No-visa entry was most common during the 1990s in both France and Italy, while it was most prevalent in Spain during the 2000s. This figure also makes it clear that no-visa entry has been more common in all periods in both Italy and Spain than in France.

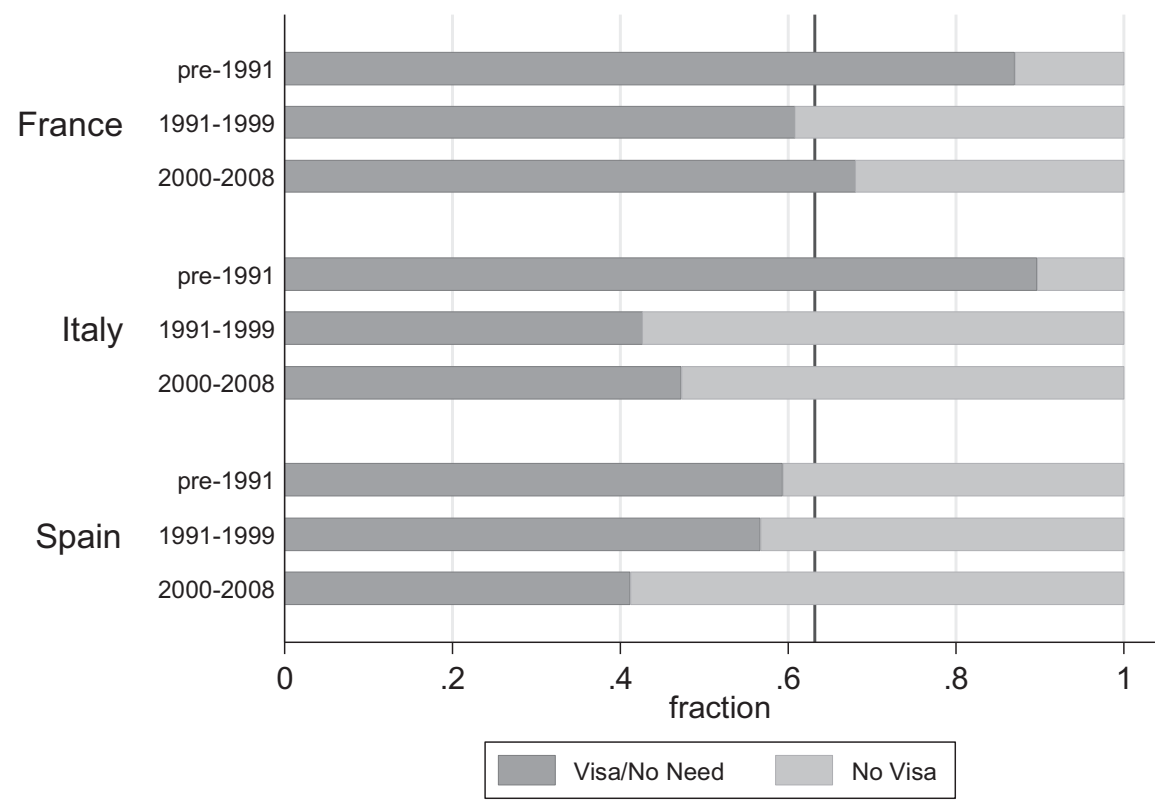

Fig. 3.2 Entry status by destination and period. (Source: MAFE-Senegal. Weighted proportions. Vertical line represents mean of entry with visa) 
Model 1 confirms that no-visa entry is more common in Italy and Spain and in earlier periods. Table 3.4 displays the results of the logistic regression of no-visa entry described by Eq. (3.1) in the form of average marginal effects (AMEs). This model reproduces the main insights of the descriptive statistics regarding context, while adjusting estimates for a host of other contextual and individual variables. Compared to migrants in France, migrants are 14 percentage points more likely to start a migration spell in Spain without a visa, and 18 percentage points more likely to do so in Italy. The relationship between period of arrival and the probability of no-visa entry is even greater: compared to those migration spells starting before 1991, migrants arriving in the 1990s experienced a 24-point increase in the probability of no-visa entry, while for arrivals in the 2000s the increase was 26 points. Perhaps counterintuitively, migrating during the year of a regularization program is negatively associated with entering without a visa (but only at $p<.10$ ).

Because the model includes an interaction between destination and period (which is taken into account when calculating average marginal effects), it is also possible to examine how destination and period work together to shape this pathway. Figure 3.3 shows the predicted probability of no-visa entry for each combination of destination and period and confirms that the probability of no-visa entry to Italy has been almost $60 \%$ since 1991, statistically significantly higher than all periods in France and the pre-1991 period in both Spain and Italy. While there is no statisti-

Table 3.4 Average marginal effects of models for no-visa entry, overstaying, and befallen irregularity

\begin{tabular}{|c|c|c|c|c|c|c|}
\hline \multirow[b]{3}{*}{ Predictor } & \multicolumn{6}{|l|}{ Outcome } \\
\hline & \multicolumn{2}{|l|}{$\begin{array}{l}\text { I. No-visa } \\
\text { entry }^{b}\end{array}$} & \multicolumn{2}{|c|}{ II. Overstay } & \multicolumn{2}{|c|}{$\begin{array}{l}\text { III. Befallen } \\
\text { irreg. }^{d}\end{array}$} \\
\hline & AME & se & AME & se & AME & se \\
\hline \multicolumn{7}{|l|}{ Context } \\
\hline \multicolumn{7}{|l|}{ Period (ref.: pre-1991) } \\
\hline $1991-2000$ & $0.24 * * *$ & 0.044 & $0.10^{*}$ & 0.046 & 0.0022 & 0.0030 \\
\hline $2000-2008$ & $0.26 * * *$ & 0.047 & $0.21 * * *$ & 0.045 & -0.0018 & 0.0024 \\
\hline \multicolumn{7}{|l|}{ Destination (ref.: France) } \\
\hline Spain & $0.14 * *$ & 0.051 & $0.12 *$ & 0.052 & 0.00063 & 0.0023 \\
\hline Italy & $0.18 * * *$ & 0.050 & 0.083 & 0.054 & 0.0032 & 0.0026 \\
\hline Regularization year (ref.: no) & $-0.067^{+}$ & 0.036 & $0.078 *$ & 0.035 & 0.0022 & 0.0014 \\
\hline \multicolumn{7}{|l|}{ Previous migration experience } \\
\hline \multicolumn{7}{|l|}{ Previous mig. exp.(ref.: none) } \\
\hline Previous mig. exp. w/visa & -0.0056 & 0.075 & - & - & - & - \\
\hline Previous mig. exp. w/out visa & $0.34 * *$ & 0.12 & - & - & - & - \\
\hline Entry status (ref.: no visa) & - & - & $0.11 * *$ & 0.036 & 0.0014 & 0.0014 \\
\hline \multicolumn{7}{|c|}{ Origin legal status (ref.: RP_NWP) } \\
\hline Mixed (NRP_WP) & - & - & - & - & 0.0012 & 0.0057 \\
\hline Fully regular (RP_WP) & - & - & - & - & $-0.0061 *$ & 0.0030 \\
\hline Return migrant (ref.: no) & $0.20 * *$ & 0.065 & $-0.14 *$ & 0.062 & 0.00027 & 0.0030 \\
\hline
\end{tabular}


Table 3.4 (continued)

\begin{tabular}{|c|c|c|c|c|c|c|}
\hline \multirow[b]{3}{*}{ Predictor } & \multicolumn{6}{|l|}{ Outcome } \\
\hline & \multicolumn{2}{|l|}{$\begin{array}{l}\text { I. No-visa } \\
\text { entry }\end{array}$} & \multicolumn{2}{|c|}{ II. Overstay ${ }^{c}$} & \multicolumn{2}{|c|}{$\begin{array}{l}\text { III. Befallen } \\
\text { irreg. }^{d}\end{array}$} \\
\hline & AME & se & AME & se & AME & se \\
\hline \multicolumn{7}{|l|}{ Forms of capital } \\
\hline Years of education & $-0.008 *$ & 0.003 & $-.01 * * *$ & 0.003 & 0.00011 & 0.0002 \\
\hline Speaks language of dest. (ref.: yes) & $-0.066^{+}$ & 0.036 & 0.012 & 0.041 & $-0.0029^{+}$ & 0.0017 \\
\hline Financial help of family (ref.: no) & -0.052 & 0.039 & $-0.084 *$ & 0.038 & 0.00046 & 0.0022 \\
\hline $\begin{array}{l}\text { Self-reported economic status (ref.: } \\
\text { bad) }\end{array}$ & $-0.13^{*}$ & 0.057 & 0.052 & 0.086 & -0.0027 & 0.0023 \\
\hline Number of contacts at dest. & 0.0025 & 0.016 & -0.014 & 0.009 & -0.00041 & 0.0007 \\
\hline Number of trips & - & - & $-0.1 * * *$ & 0.021 & $0.0012 *$ & 0.0005 \\
\hline \multicolumn{7}{|l|}{ Links to social institutions } \\
\hline Kids at dest. (ref.: no) ${ }^{\mathrm{a}}$ & -0.019 & 0.054 & $-0.14 *$ & 0.060 & -0.0027 & 0.0020 \\
\hline Spouse at dest. (ref.: no) ${ }^{\mathrm{a}}$ & 0.022 & 0.049 & $-0.13 * *$ & 0.047 & 0.00049 & 0.0025 \\
\hline \multicolumn{7}{|l|}{ Economic activity (ref.: inactive) } \\
\hline Unemployed $^{\mathrm{a}}$ & 0.028 & 0.068 & $0.19 *$ & 0.076 & 0 & . \\
\hline Employed $^{\mathrm{a}}$ & -0.039 & 0.041 & $0.11 *$ & 0.047 & $-0.01 * * *$ & 0.0017 \\
\hline Definitive plans to stay (ref.: no) & $0.059^{+}$ & 0.034 & 0.011 & 0.033 & 0.00017 & 0.0018 \\
\hline $\begin{array}{l}\text { Migration motive: work (ref.: not } \\
\text { work) }\end{array}$ & -0.021 & 0.036 & 0.026 & 0.038 & -0.00029 & 0.0020 \\
\hline \multicolumn{7}{|l|}{$\begin{array}{l}\text { Individual sociodemographic } \\
\text { characteristics }\end{array}$} \\
\hline Age at migration & $0.0056^{*}$ & 0.002 & -0.0036 & 0.003 & 0.000052 & 0.0001 \\
\hline Sex: male (ref.: female) & 0.046 & 0.044 & -0.066 & 0.041 & 0.00029 & 0.0025 \\
\hline Ethnicity: Wolof (ref.: other) & 0.031 & 0.035 & 0.043 & 0.037 & $-0.0045^{*}$ & 0.0020 \\
\hline Religion: Mouride (ref.: other) & $0.13 * * *$ & 0.036 & 0.062 & 0.038 & -0.0017 & 0.0017 \\
\hline Geographic origin: Dakar (ref.: other) & -0.019 & 0.035 & $0.087^{*}$ & 0.035 & $0.0046^{+}$ & 0.0027 \\
\hline $\begin{array}{l}\text { Father's education: < secondary (ref.: } \\
>\text { ) }\end{array}$ & -0.040 & 0.035 & 0.053 & 0.036 & 0.00020 & 0.0018 \\
\hline Status duration (years) & - & - & - & - & $-0.001^{*}$ & 0.0004 \\
\hline Num. of status spells & - & - & - & - & $-0.0080 *$ & 0.0031 \\
\hline $\mathrm{N}$ & \multicolumn{2}{|l|}{763} & \multicolumn{2}{|l|}{763} & \multicolumn{2}{|l|}{6731} \\
\hline Log likelihood & \multicolumn{2}{|l|}{-395.37} & \multicolumn{2}{|l|}{-690.40} & \multicolumn{2}{|l|}{-1577.11} \\
\hline Pseudo $\mathrm{R}^{2}$ & \multicolumn{2}{|l|}{0.2045} & \multicolumn{2}{|l|}{0.2262} & \multicolumn{2}{|l|}{0.2290} \\
\hline
\end{tabular}

Source: MAFE-Senegal

Notes: ${ }^{+} p<0.1,{ }^{*} p<0.05,{ }^{* *} p<0.01,{ }^{* * *} p<0.001$. Average marginal effects displayed. Models include interaction between destination and period

${ }^{a}$ Variable measured prior to migration for model I

${ }^{b}$ Logistic regression of no-visa entry

${ }^{\mathrm{c}}$ Multinomial logistic regression of four legal-status categories

${ }^{\mathrm{d}}$ Discrete-time survival model (logistic regression) of status change to NRP_NWP (fully irregular) 


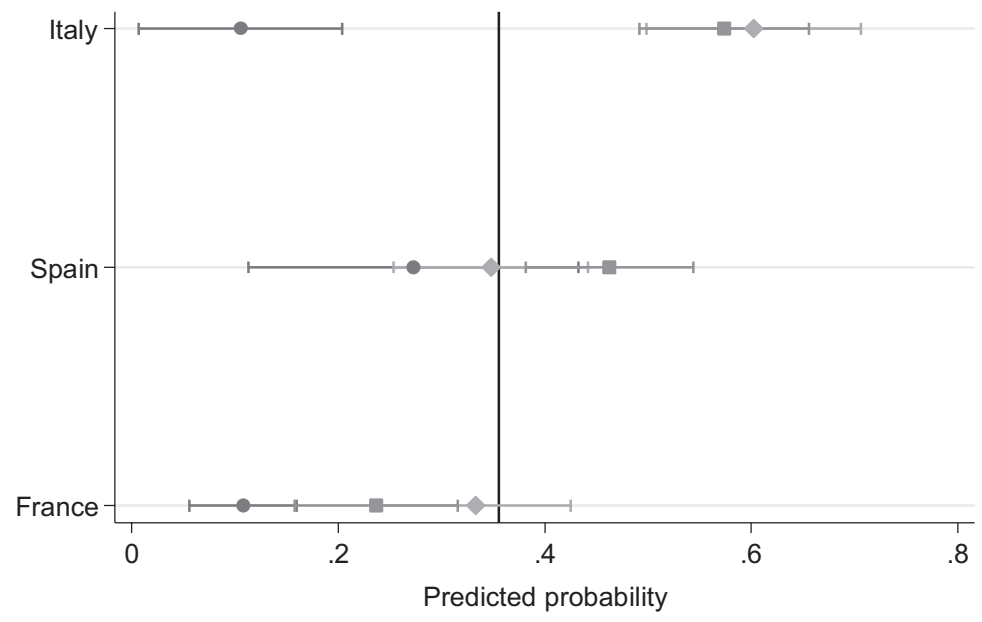

- pre-1991 1991-1999 2000-2008

Fig. 3.3 Predictive margins of no-visa entry, by destination and period, with $95 \%$ confidence intervals. (Source: MAFE-Senegal. Vertical line represents average predictive margin)

cally significant difference in the predicted probability of no-visa entry in Spain between periods, the pattern found in the descriptive statistics of a monotonic increase over time remains. No-visa entry seemed to peak in France in the 1990s, but both later periods have predicted probabilities of no-visa entry that are statistically significantly higher than the pre-1991 period. It is thus clear that context, both in terms of destination and period of arrival, plays an important role in shaping access to the no-visa pathway to irregularity, and that this pathway is more common in Southern Europe (especially Italy).

While the indicators for destination country and period could capture the effects of a number of factors, such as economic conditions, there is reason to suspect that the increase in entry without a visa over time and in southern Europe is related principally to the evolution towards increased restrictiveness in the legal context. France's immigration policy evolved in a restrictive direction, and the southern European countries went from a complete lack of a national-level immigration framework to a system designed to plug perceived holes in Mediterranean borders. The increase in no-visa entry over time, especially in southern Europe, is indicative of the creation of this pathway of irregularity by immigration policy.

In addition to shedding light on the contextual factors shaping no-visa entry, Model I of Table 3.4 suggests other factors associated with this pathway to irregularity. There is a strong link to previous irregular experience: having entered a destination without a visa during a previous migration spell is associated with an increase in the probability of no-visa entry of 34 points. Indeed, this is the strongest predictor of no-visa entry in terms of magnitude, and thus offers evidence of the path-dependence of irregular status. This effect can also be interpreted as a form of 
migration-specific capital: migrants draw on knowledge and skills gained on previous trips starting with an unauthorized entry to make future unauthorized entry more likely. Returned migrants are also 20 percentage points more likely to have started their trips without a visa.

In addition to migration-specific capital, other forms of capital are also associated with no-visa entry as hypothesized. Financial capital plays a role in irregular entry: while there is no association between family resources, social class (as measured by father's education), or employment prior to migration with no-visa entry, good subjective economic status is associated with a lower probability of no-visa entry. This suggests that visas are selective of the economically successful, but research has also shown that resources of many kinds are necessary for irregular entry (for travel, passeur fees, etc.). There is also evidence of other forms of capital: belonging to the Mouride Islamic brotherhood is associated with an increase of 13 points in the probability of migrating without a visa; this brotherhood is well known for facilitating the migration of its members by providing social and economic support (Kaag 2008; Riccio 2008), and this finding suggests that its members can draw on the social capital in this network for resources to circumvent entry restrictions. There is no evidence in the model of associations between links to family in destination and the probability of no-visa entry, which indicates those migrants who have families in the destination country do not attempt to rejoin them via this pathway and suggests that families wishing to reunify have access to channels that permit legal entry.

\subsubsection{Pathway: Overstaying}

Results for overstaying suggest once again the importance of context and access to forms of capital for this pathway to irregularity, and also show the importance of links to institutions at the destination. Figure 3.4 shows the first legal status of Senegalese migrants' migration spells by both destination and entry status. This figure suggests that migrants in France are more likely to transition to fully regular (RP_WP) status following arrival than migrants in Italy or Spain; the proportion of migrants transitioning to this status in France is close to half regardless of entry status, while it is much lower in both Spain and Italy. Most of this difference seems to be explained by higher probabilities of transition to fully irregular first status (NRP_NWP) in the southern European countries. In addition, a higher proportion of migrants entering with a visa transition to fully irregular first status in Italy and Spain than in France. Indeed, in France, entering without a visa seems to be associated with increased probability of transitioning to irregular status, indicating that irregular entry is more closely associated with irregular status in the first year. Thus, irregular first status is higher overall in the southern European countries and in particular for those migrants who enter with a visa, suggestive of overstaying in Italy and Spain. 


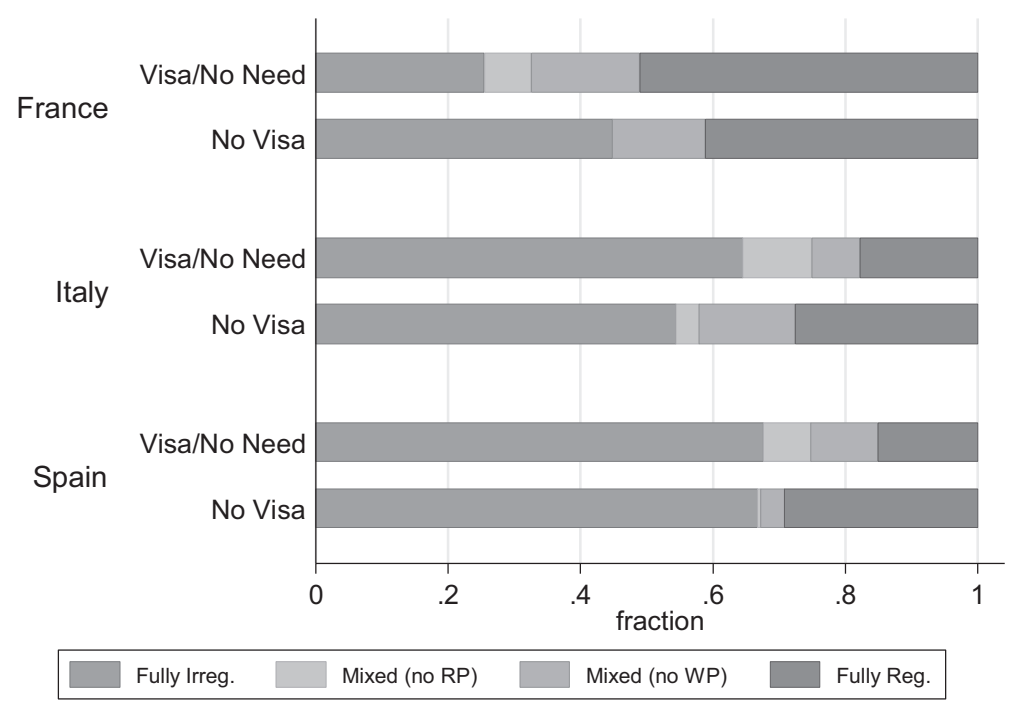

Fig. 3.4 First legal status by destination and entry status. (Source: MAFE-Senegal. Weighted proportions)

Table 3.4 shows selected results for the multinomial logistic regression of model 2. While the model includes all four legal-status categories in the dependent variable, ${ }^{2}$ Table 3.4 only displays average marginal effects for the probability of fully irregular (NRP_NWP) first status as the pathway of interest concerns transition from having an entry visa to fully irregular status. The model confirms the descriptive results: on average, entering with a visa is associated with an increase of 11 percentage points in the probability of having a fully irregular first legal status. This result, while seemingly counterintuitive, suggests that irregularity is not merely the result of irregular entry and, conversely, that illegal entry does not lead to permanent irregularity.

The probability of irregular status during the year of arrival also varies by destination: the model confirms that irregular first status is more common in southern Europe: the probability of first-status irregularity is 14 and 11 percentage points higher in Italy and Spain, respectively, than France. The effects of period of arrival are also evident: arrival in the 1990s is associated with an increase of 11 percentage points in the probability of transition to irregular first status, while the increase is 26 points for the 2000s. Arriving during the year of regularization is positively associated with the probability of having irregular status upon arrival, suggesting that Senegalese migrants may have sought out destinations for the regularization opportunities they offered at certain points in time.

\footnotetext{
${ }^{2}$ While "NRP_NWP" was identified as the base category for modeling purposes, it is possible to calculate the average marginal effects related to the probability of this category since the probabilities of all categories must sum to unity.
} 


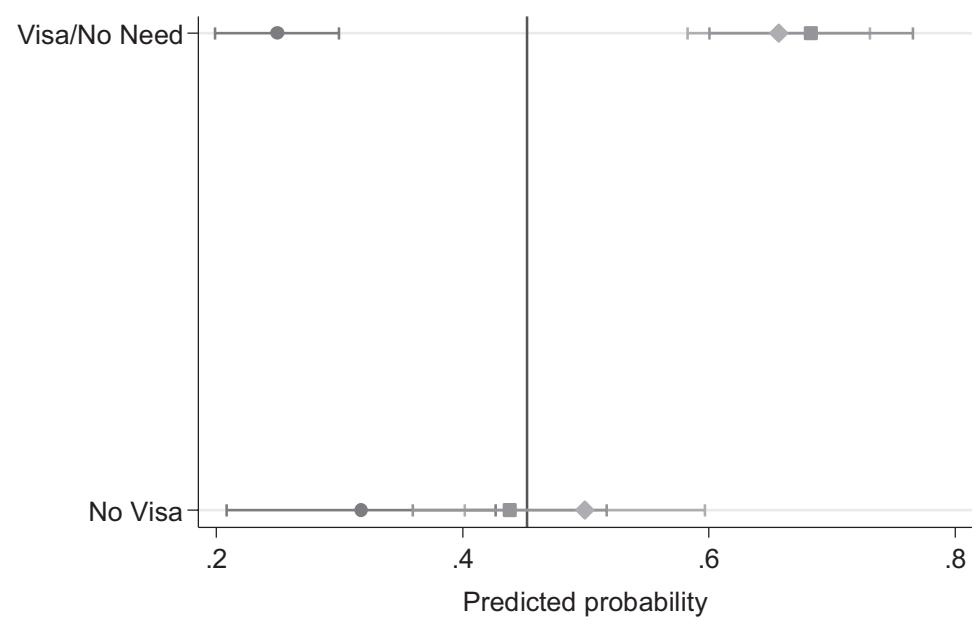

- France Spain Italy

Fig. 3.5 Predictive margins of NRP_NWP first status, by entry status and destination, with 95\% confidence intervals. (Source: MAFE-Senegal. Vertical line represents average predictive margin)

The model allows an examination of how the effect of entering with a visa varies by context. Figure 3.5 displays the predicted probabilities of NRP_NWP first status by entry status and destination and shows that the probability of transitioning to irregular status after arrival is higher for migrants with visas in Italy and Spain than in France. Conversely, there is no statistically significant difference in the probability of this transition between the three countries for migrants entering without visas. The positive effect of entering with a visa on the probability of being irregular during the year of arrival is thus concentrated in the southern European destinations, and the effect is strongest in Italy, as Fig. 3.6 shows. There is thus ample evidence that this pathway is produced by variation in context, both geographically and over time.

Social, migration-specific, and financial forms of capital are negatively associated with becoming irregular during the first year of residence. As Model II of Table 3.4 shows, the probability of first-status irregularity decreases with the number of contacts at destination, the number of previous migration spells, the financial participation of the migrants' family, and the migrants' self-reported economic status before the trip. Access to a variety of resources thus protects against first-status irregularity. Having children in the destination country is also associated with reduced probability of first-status irregularity, as is having a spouse at destination (although the effect is not statistically significant), indicating that family links at destination help protect migrants from irregularity. Returned migrants are also less likely to have been in fully irregular status during their year of arrival despite having a higher probability of having entered without a visa. Other factors are positively associated with this pathway: being from Dakar and migrating for work/a better life 


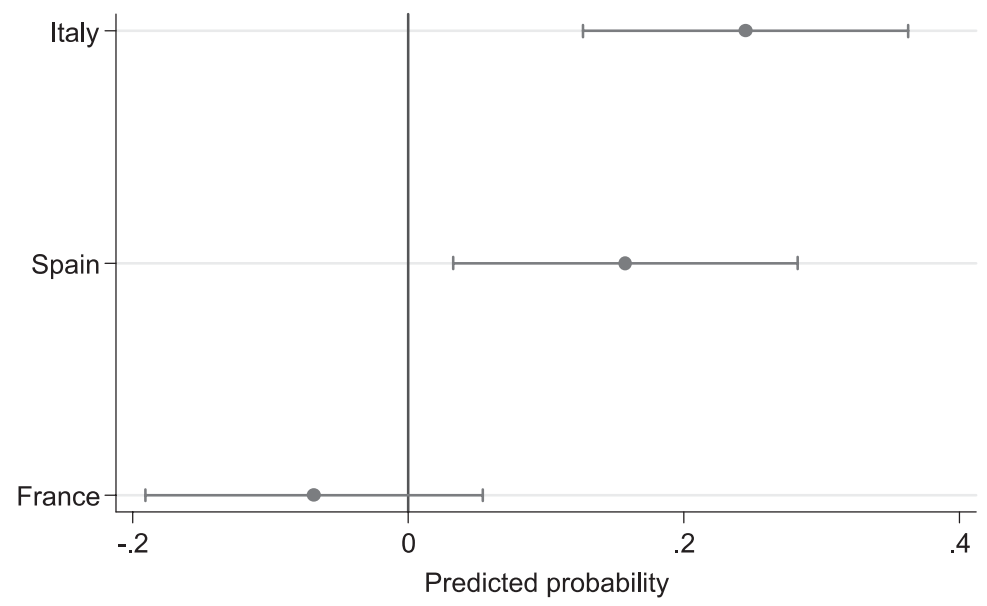

Fig. 3.6 Average marginal effect of entry with visa on NRP_NWP first status, with 95\% confidence intervals. (Source: MAFE-Senegal)

are positively associated with the probability of first-status irregularity, and belonging to the Mouride brotherhood is marginally positively associated with this outcome $(p=0.051)$.

\subsubsection{Pathway: Befallen Irregularity}

Unlike the pathways of no-visa entry and overstaying, the determinants of the pathway of befallen irregularity are prior legal status, while there is little evidence of contextual variation or relationship to forms of capital. The overall probability of transition from fully regular or semi-irregular statuses to fully irregular status is quite low: a basic life table (not reported) indicates that less than $4 \%$ of migrants at risk for this transition ever actually experience it. This provides descriptive evidence that migrants with fully regular or semi-irregular statuses are unlikely to transition to fully irregular status. This finding is borne out by the graphical transition matrix of Fig. 3.7, which shows that transitions into full irregularity are rare among migrants who change status; indeed, the most common transitions seem to be into fully regular status (RP_WP).

Model III of Table 3.4 displays results from the discrete-time survival analysis of befallen irregularity, and indicates that origin legal status - the status from which a migrant may transition into fully irregular status - is one of the strongest sets of predictors in the model. Migrants with fully regular status are less likely to transition to irregular status than those with either semi-irregular status. Figure 3.8 depicts predicted probabilities of befallen irregularity and shows that the predicted probability for fully regular migrants of transitioning to fully irregular status is less than half of the average predicted probability for migrants with semi-irregular statuses. 


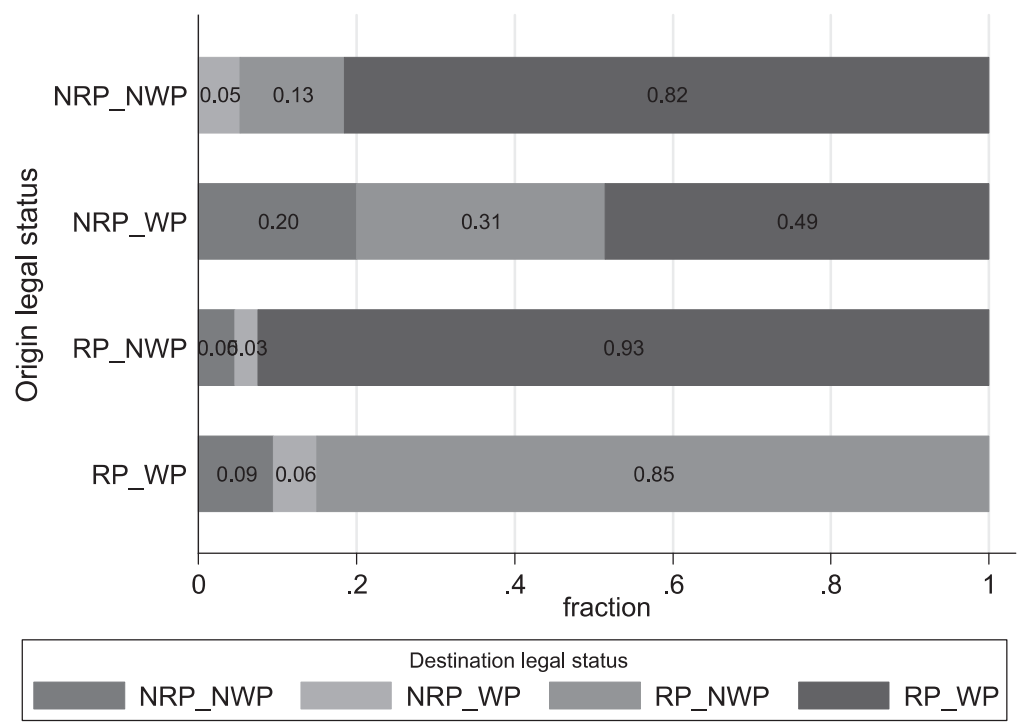

Fig. 3.7 Legal status transitions. (Source: MAFE-Senegal. Horizontal line represents average predictive margin)

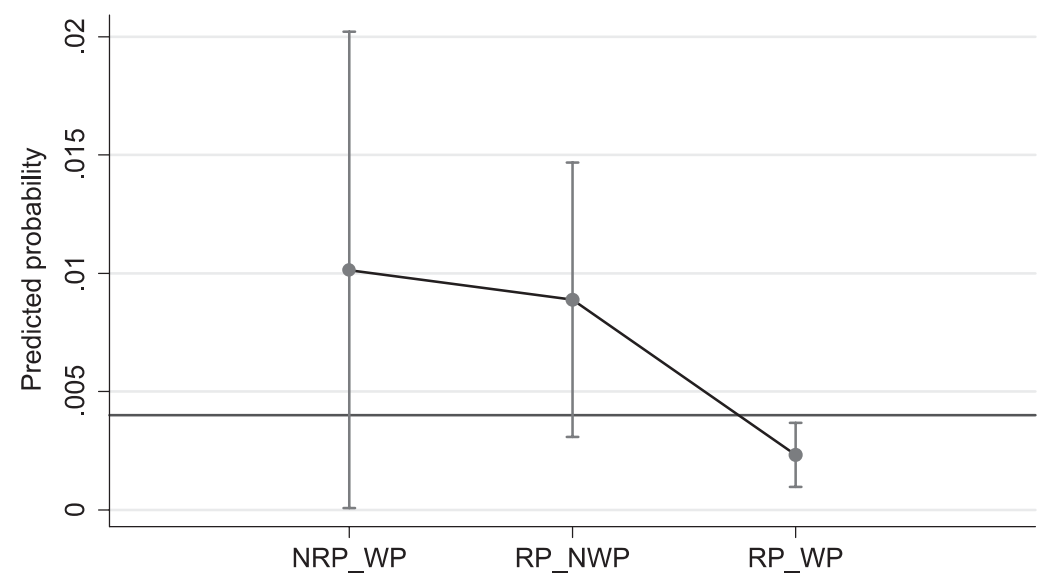

Source: MAFE - Senegal. Horizontal line represents average predictive margin.

Fig. 3.8 Predictive margins of transition to NRP_NWP, by prior status, with 95\% confidence intervals

There is thus evidence that fully regular status is quite "sticky," i.e., transitions from it into full irregularity are rare. The low (close to $1 \%$ ) predicted probabilities of befallen irregularity for migrants with semi-irregular legal status suggest that transitions into full irregularity are rare from any prior status. 
Unlike previous pathways, context—destination and period of arrival-does not have a statistically significant relationship with befallen irregularity. While origin legal status is strongly related to the probability of transitioning to fully irregular status, entry status is not. Forms of capital are also not significantly related to this transition, with the exception of the number of previous migrations. The positive relationship between number of migrations and the probability of befallen irregularity suggests that previous migration experience may help navigate a destination's institutions and labor market in an irregular status. Among predictors indicating links to destination institutions, only the employment variable is associated with befallen irregularity: being unemployed is negatively related to this transition. Surprisingly, neither having a spouse nor having children in the same destination is protective of falling into irregularity.

Among the remaining predictors, the duration of the legal status before transition, the number of legal-status spells, and Wolof ethnicity are all negatively related to the probability of transitioning to fully irregular status. The duration and number of spells variables indicate that transitions to irregularity, if they occur, happen early in migrants' stay in a destination country, and that experiencing multiple kinds of legal status help migrants avoid fully irregular status. While indicators of context are not statistically significantly related to befallen irregularity, the ethnicity and employment variables are suggestive of contextual effects. Non-Wolof migrants are concentrated in France, and literature suggests they are mainly Soninké from earlier migration flows (Timera and Garnier 2010); this may be indicative of transitions to irregularity under France's somewhat lax immigration regime of the 1960s and early 1970s.

\subsection{Discussion}

Literature on the pathways into irregular legal status has drawn on insights from research on the "legal production of illegality" to insist on the importance of context in setting the parameters that shape the pathways in a given context of reception. This literature has also challenged dominant binary conceptualizations of legal status by examining multiple forms of irregularity and changes in these often-fuzzy statuses over time. This chapter has drawn on these insights to study three pathways into irregular status among Senegalese migrants in France, Italy, and Spain: no-visa entry, overstaying, and befallen irregularity.

In keeping with the literature on the legal production of illegality, this chapter hypothesized that context — both destination country and period-would play a preponderant role in structuring all of the pathways by setting the legal parameters of irregularity. The results, however, showed that context was more important in structuring pathways that occur early in the migrant's trajectory-no-visa entry and overstaying-than subsequent transitions to irregularity. The pathway of no-visa entry was more likely in Spain and Italy than in France, and the prevalence of no-visa entry rose monotonically over time in the southern European countries, while it peaked in 
France in the 1990s. Context likewise had a strong association with the pathway of overstaying: irregular first status more likely for those entering with visa in Italy and Spain than in France, with the strongest relationship in Italy. The probability of irregular first status also increased monotonically over time by period of arrival.

The effects of context were less clear, however, for changes in legal status once migrants were established at the destination. There was virtually no direct relationship between context and befallen irregularity. This contrasts with research that shows that status transitions are common in southern Europe (Fasani 2010; González-Enríquez 2010) or with the review in Chap. 2 that outlines the multiplication of various pathways into irregularity. These findings suggest that context is more important in shaping the pathways that occur closer in time to the act of crossing a border.

The political discourses (Vollmer 2011) and resources devoted to border control in all three destinations (Courau 2009; Fasani 2010; González-Enríquez 2010) may help make sense of the stronger relationship that contextual indicators have to these earlier pathways. The policy and legal parameters surrounding entry have varied the most between destinations and over time, with a pronounced evolution towards restrictiveness and a resultant externalization of control mechanisms (Brochmann 1999). Increased border surveillance and tighter visa requirements are common responses in France, Italy, and Spain to political pressures at both the national (Freedman 2004; González-Enríquez 2009; Sciortino 1999) and EU level (Finotelli and Sciortino 2009) to appear "in control" of migration.

As many studies of immigration control have shown, though, policies often have unintended consequences (Brochmann 1999). Increased external controls have created irregular entry flows directly by definition, and have, as a result, transformed regular flows into irregular ones. At the same time, these restrictive entry policies will make migrants less likely to depart once in destination because of increased risk and costs of entry; this may favor the production of irregularity in the first legal status at destination. These dynamics resemble features of the Mexico-United States migration system, where increased border control has done little to prevent undocumented migration as measured by apprehension probabilities and has instead led to longer stays of undocumented migrants because of the increased price and risk of undocumented border crossing (Massey et al. 2002, 2016). The increases of no-visa entry and overstaying thus underline that irregularity is a manufactured state rather than a characteristic of the migrants themselves.

In contrast, policy attention given to border control and controlling geographic flows has often meant a relative negligence of frameworks governing migrants' integration once at destination (Finotelli and Sciortino 2009; Freedman 2004; GonzálezEnríquez 2009; Sciortino 1999). This is borne out by the MAFE-Senegal data: changes of status are somewhat rare (less than $50 \%$ of the sample changed status), and they are not tightly linked to context. This suggests that those transitions that do take place may not be systematically produced by sociolegal frameworks that vary over destination and time, but instead are embedded in logics of integration that have not been major policy concerns, perhaps because of general acceptance or ignorance of migrants' irregular status once they are established at a destination. 
This chapter also drew on the literature on expanded conceptualizations of irregularity to hypothesize that there would be systematic links between various pathways of irregularity. Prior no-visa entry was strongly predictive of current no-visa entry. Previous undocumented border crossing could thus be considered as a form of migration-specific capital that makes future undocumented trips more likely, a finding that is common in the US context (Massey and Espinosa 1997). Entering with a visa on the current trip, on the other hand, was strongly predictive of transition to fully irregular first legal status in Italy and Spain. For these migrants, a visa may simply be a springboard into informal employment in societies that have a higher tolerance of irregularity; in France, on the other hand, even migrants with visas have a fairly low predicted probability of transitioning to fully irregular status, implying that there may be more stable paths to regularity or more intolerance of irregularity there. In contrast, there was no association between entry status and subsequent transitions to irregularity, indicating that befallen irregularity later in Senegalese migrants' stays at destination is not related to the mode of entry. At the same time, the results from the transition model suggest that legal statuses are sticky: migrants with fully regular status were less likely to transition to irregular status than those with semi-irregular statuses, indicating that fully regular status is difficult to lose once gained. Once again, this could be interpreted as a form of capital, this time in the legal domain: Senegalese migrants are able to convert their experience in regular status into a lower probability of falling into irregularity.

Taken together, these results paint a picture of interlinked pathways of irregularity with complex relationships between different pathways. Entry with a visa, not irregular entry, is closely related to first-status irregularity in southern Europe, while it is unrelated to later transitions into irregular status. While policies focus on preventing irregular entry, these results show that this externalization of control may simply be deferring Senegalese migrants' irregularity to after arrival and creating demand for regularization mechanisms, either through formal programs or entitlement-based adjustments of status. Externalization of control, while able to curb some irregular flows, seems to do little to prevent other forms of irregularity; indeed, it creates a robust pathway into irregularity in the form of overstaying.

Forms of capital, identified in much previous research as important correlates of both migration and integration, seem to be similar to context in that they are important for access to pathways that occur early on in the migration spell, and fade in importance for subsequent transitions. Entry without a visa was less likely for those migrants who self-reported good economic status prior to the migration, indicating that those who perceive themselves as better-off have easier access to visas. Indeed, the requirements for proof of resources and the financial means or ticket for the return trip that exist in most countries' visa policies are a built-in method of selecting potential migrants on economic lines, and they must mobilize significant resources to meet these requirements (Sciortino 2004). Previous no-visa entry and belonging to the Mouride brotherhood were positively associated with the probability of no-visa entry, pointing to the importance of migration-specific and social forms of capital in this pathway. Transition to first-status irregularity was the pathway the most strongly related to forms of capital: financial (family financial help 
and self-reported economic status), social (number of contacts at destination), and migration-specific (number of previous migrations) forms of capital all reduced the probability of irregular first status. While entering with a visa is resource-intensive, gaining regular legal status once in destination is even more so.

In contrast, there was almost no relationship between these indicators of access to resources and the probability of falling into fully irregular status. Instead, this transition seems to be more related to the migrant's connection to institutions in the destination country. Having children in the destination country is associated with a reduced probability of first-status irregularity, as is having a spouse at destination. These family links thus seem to be protective against transitions into less-secure irregular statuses. While this chapter has not examined the timing of the formation of unions or the birth of children and thus cannot speak to the exact mechanism behind these associations, migrants may be accessing regular status through legal provisions for family attachment, such as family reunification or marriage to citizens.

In addition to the family, the labor market is another institution that plays a role in structuring transitions between legal statuses. Unemployment is associated with a lower probability of befallen irregularity. Thus, holding a job is not necessarily protective against befallen irregularity. While somewhat paradoxical from the point of view of the literature that argues that unemployment can lead to irregularity through the loss of a formal job contract that would allow renewal of work and residence permits, the association between employment and befallen irregularity could be an indication that Senegalese migrants who lose regular legal status are concentrated in informal labor markets. The fact that previous migration experience is also associated with befallen irregularity suggests that this form of migration-specific capital may help migrants navigate institutions such as the informal labor market (Reyneri 1998). Thus, befallen irregularity might be part of a logic of accumulation at the expense of documentation, which research suggests might be common among Senegalese migrants in Spain (van Nieuwenhuyze 2008).

\subsection{Conclusion}

Irregular migration is a controversial topic in most migrant-receiving countries around the world. Recent estimates put the undocumented population of the US at over ten million (Passel and D'Vera Cohn 2011), while Europe's irregular population is estimated to be somewhere between three and five million (Düvell 2011b). Unfortunately, understanding of this phenomenon in Europe is hampered by policy discourses and political processes that use "numbers games" (Sciortino 2004; Vollmer 2011) to placate public outcry over irregular migration by increasing border controls at the expense of the integration of migrants already in destination countries. While academic research has sought to improve methods of "counting the uncountable" to better frame policy debates, many studies have used a simplified dichotomous conceptualization of irregular status that both privileges examinations 
of only one pathway to irregularity (undocumented border crossing) and hides heterogeneity in legal statuses.

This chapter has attempted to contribute to the growing literature calling for a more complex conceptualization of irregularity by examining the pathways into a set of irregular statuses among Senegalese migrants in Europe. Context plays a strong role in shaping no-visa entry and overstay, pathways that occur early in the migration trajectory. These pathways are likely to be the most responsive to variation over time and across destination of the sociolegal parameters of legal status since most of these parameters have increasingly converged on preventing irregular entry. These early pathways of irregularity are also responsive to migrants' various forms of capital: migrants who have greater access to financial, human, and social capital are less likely to follow these paths into irregularity; migration-specific social capital in the form of prior no-visa entry facilitate current no-visa entry, but an increase in the number of previous trips protects against first-status irregularity. On average, then, access to resources gives migrants more options in terms of legal channels.

Transitions in legal status, such as overstaying and befallen irregularity, are more responsive to links to institutions in the destination country, suggesting that migrants participate actively in seeking pathways out of irregularity as part of a project of integration (van Nieuwenhuyze 2008). Employment is, somewhat paradoxically, related to increased probability of loss of regular status, which suggests that the link between labor market participation and legal status depends crucially on whether or not the migrant works in the formal sector.

In addition to findings on context and links to institutions, this study found that previous legal status was an important predictor of all of the pathways. This supports the emerging view in research on legal status that a static binary measure of legal status is not sufficient to capture the complexity of legal status categories and transitions over migrants' life courses. This study thus contributes to the call for disaggregating legal status (Donato and Armenta 2011) and examining connections between different kinds of legal status. Furthermore, these findings present an important point of articulation with research that sees legal status as an increasingly important axis of stratification (Donato and Armenta 2011; Massey 2007) and could open the door to studies that examine status mobility in the same vein as studies of traditional social mobility. Understanding the potential structuredness and pathdependency of forms of irregularity could shed new light on the impact of irregularity on migrants' life chances. 


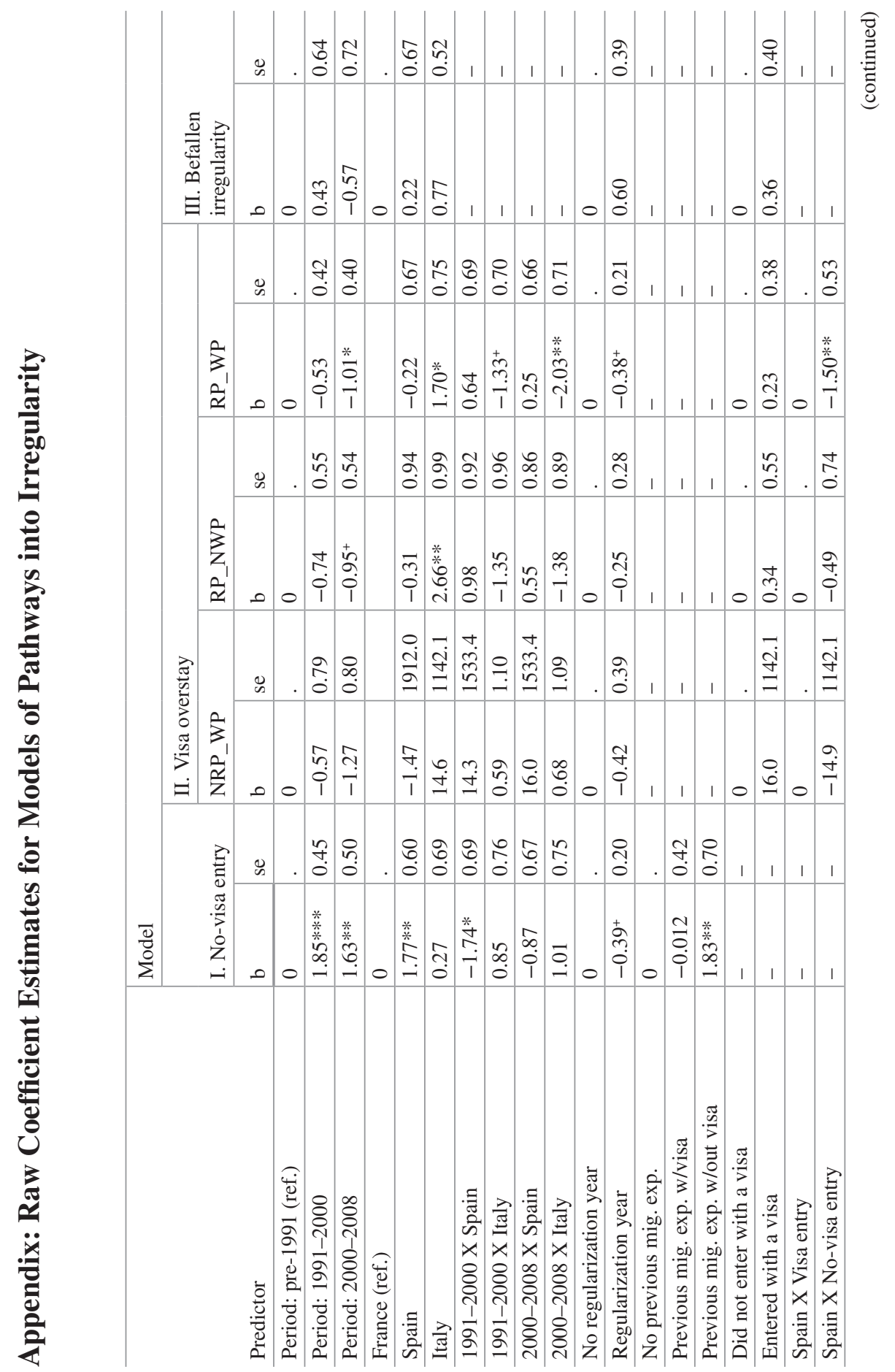




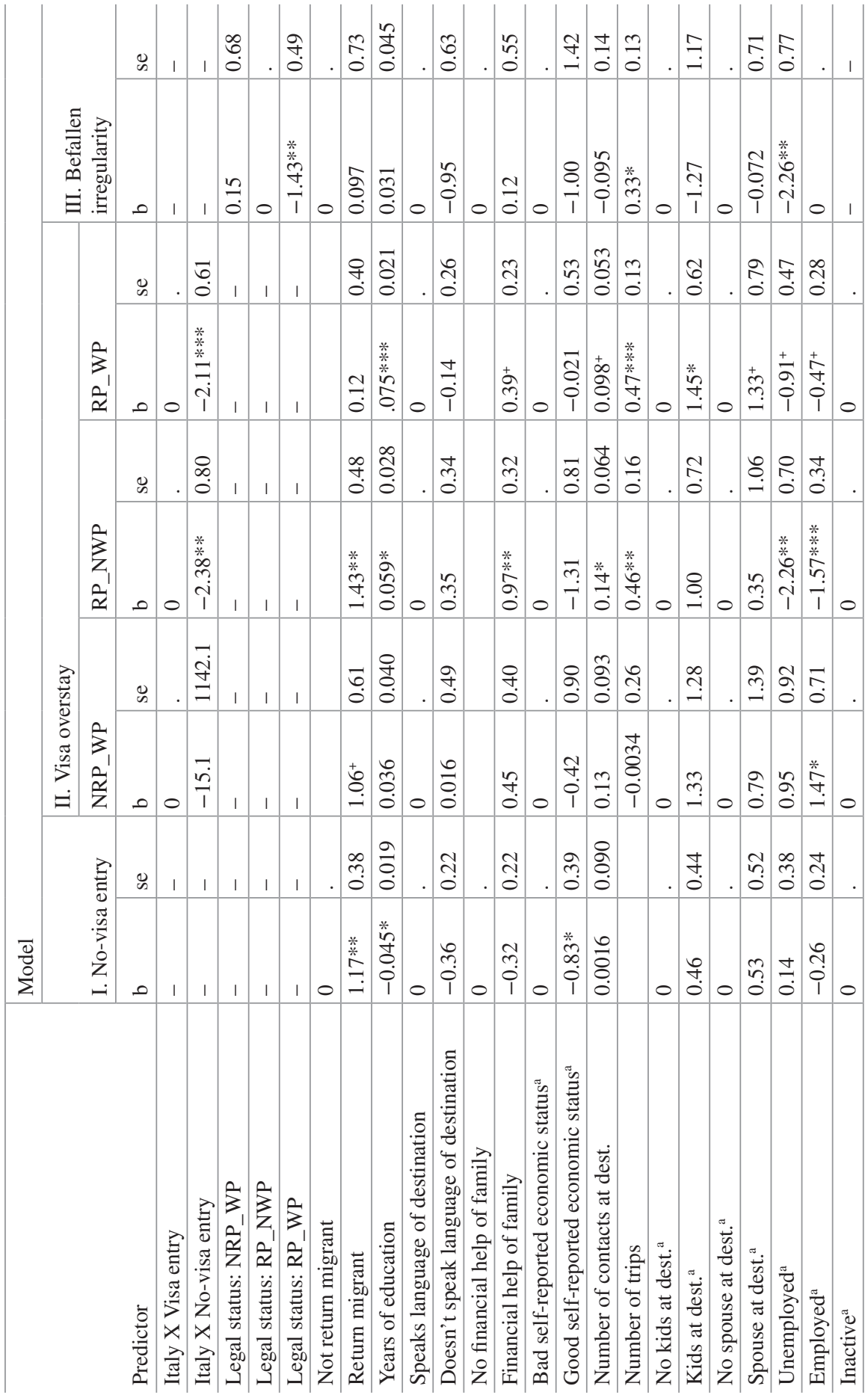




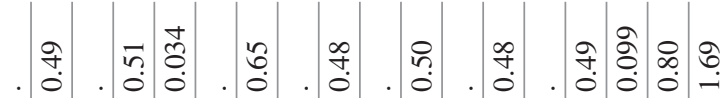

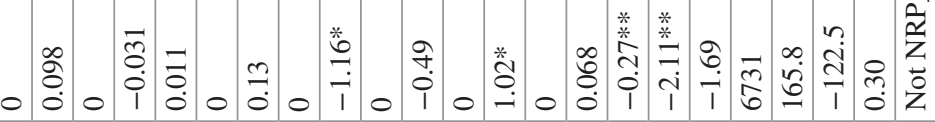

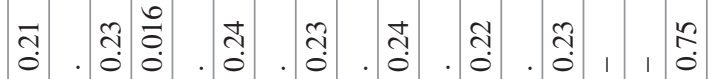

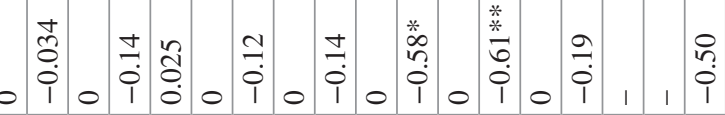

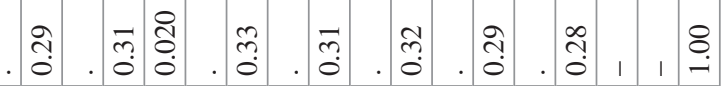

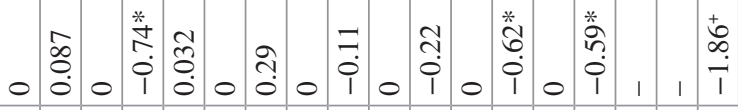

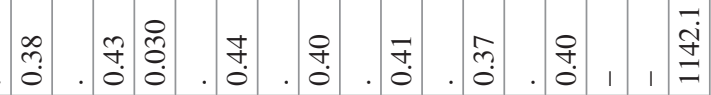

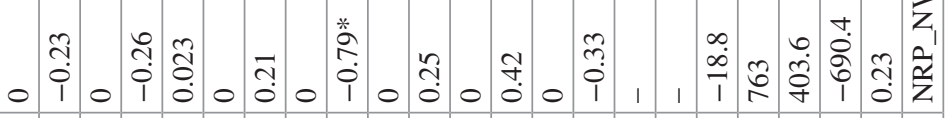

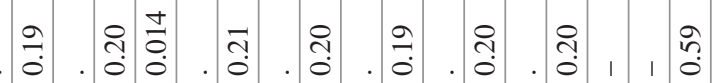

.$\pi$

喜

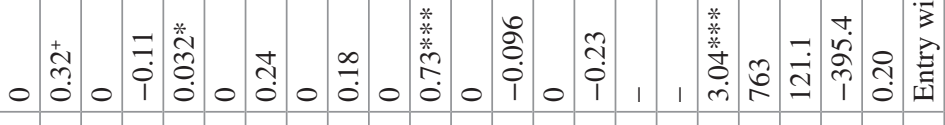

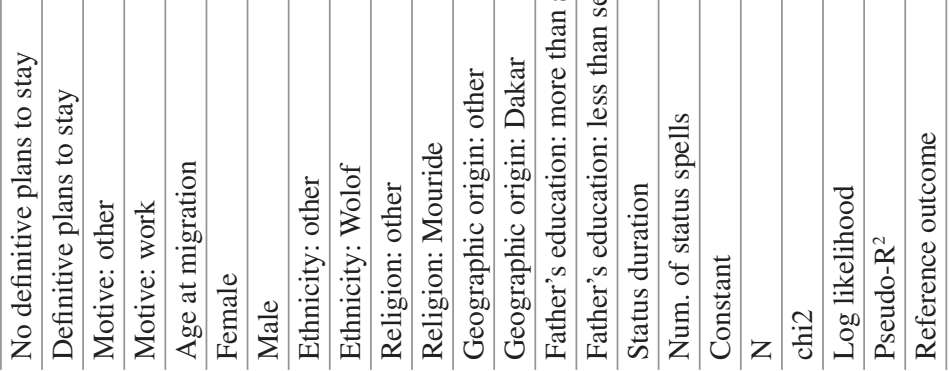

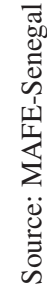


Notes: ${ }^{+} p<0.1,{ }^{*} p<0.05,{ }^{*} p<0.01, * * * p<0.001$. Logit coefficients displayed. Predictors with a "0" coefficient and a "." standard error represent reference category. Predictors with "-" listed for coefficient and standard error were not included in the model

aVariable measured prior to migration for model I

\section{References}

Alba, R. D., \& Nee, V. (2003). Remaking the American mainstream: Assimilation and contemporary immigration. Cambridge, MA: Harvard University Press.

Beauchemin, C. (2012). Migrations between Africa and Europe: Rationale for a survey design. Methodological Note (Vol. 5). Paris: INED.

Beauchemin, C. (Ed.). (2018). Migration between Africa and Europe. New York: Springer Berlin Heidelberg.

Bergues, H. (1973). L'immigration Des Travailleurs Africains Noirs En France et Particulièrement Dans La Région Parisienne. Population, 28(1), 59-79.

Borjas, G. J., \& Tienda, M. (1993). The employment and wages of legalized immigrants. International Migration Review, 27(4), 712-747.

Brochmann, G. (1999). The Mechanisms of control. In G. Brochmann \& T. Hammar (Eds.), Mechanisms of immigration control: A comparative analysis of European regulation policies (pp. 1-27). Oxford: Berg.

Calavita, K. (1998). Immigration, law, and marginalization in a global economy: Notes from Spain. Law \& Society Review, 32(3), 529-566.

Cameron, A. C., \& Trivedi, P. K. (2010). Microeconometrics using stata (Revised ed.). College Station: StataCorp LP.

Courau, H. (2009). Country report France: Undocumented migration counting the uncountable. Data and trends across Europe. CLANDESTINO project.

Coutin, S. B. (1998). From refugees to immigrants: The legalization strategies of Salvadoran immigrants and activists. International Migration Review, 32(4), 901-925.

De Genova, N. (2002). Migrant 'illegality' and deportability in everyday life. Annual Review of Anthropology, 31(1), 419-447.

Donato, K. M., \& Armenta, A. (2011). What we know about unauthorized migration. Annual Review of Sociology, 37, 529-543.

Donovon, V. (1988). Réalités Françaises et Conventions Franco-Africaines de Circulation Des Personnes. Peuples Noirs Peuples Africains, 59-62, 149-164.

Düvell, F. (2008). Clandestine migration in Europe. Social Science Information, 47(4), 479-497.

Düvell, F. (2011a). Paths into irregularity: The legal and political construction of irregular migration. European Journal of Migration and Law, 13(3), 275-295.

Düvell, F. (2011b). The pathways in and out of irregular migration in the EU: A comparative analysis. European Journal of Migration and Law, 13(3), 245-250.

Fasani, F. (2010). The Quest for La Doce Vita? Undocumented Migration in Italy. In A. Triandafyllidou (Ed.), Irregular migration in Europe: Myths and realities (pp. 115-124). Surrey: Ashgate Publishing, Ltd.

Finotelli, C., \& Sciortino, G. (2009). The importance of being southern: The making of policies of immigration control in Italy. European Journal of Migration and Law, 11, 119.

Finotelli, C., \& Sciortino, G. (2013). Through the gates of the fortress: European visa policies and the limits of immigration control. Perspectives on European Politics and Society, 14(1), 80-101.

Freedman, J. (2004). Immigration and insecurity in France. Aldershot: Ashgate.

GISTI. (2011). Le guide de l'entrée et du séjour des étrangers en France. Paris: la Découverte. 
Goldring, L., \& Landolt, P. (2011). Caught in the work-citizenship matrix: The lasting effects of precarious legal status on work for Toronto immigrants. Globalizations, 8, 325-341.

Goldring, L., Berinstein, C., \& Bernhard, J. K. (2009). Institutionalizing precarious migratory status in Canada. Citizenship Studies, 13(3), 239-265.

González-Enríquez, C. (2009). Spain, the cheap model: Irregularity and regularisation as immigration management policies. European Journal of Migration and Law, 11, 139.

González-Enríquez, C. (2010). Spain: Irregularity as a rule. In A. Triandafyllidou (Ed.), Irregular migration in Europe: Myths and realities (pp. 115-124). Surrey: Ashgate Publishing, Ltd.

González-Ferrer, A. (2011a). Explaining the labour performance of immigrant women in Spain: The interplay between family, migration and legal trajectories. International Journal of Comparative Sociology, 52(1-2), 63-78.

González-Ferrer, A. (2011b). The reunification of the spouse among recent immigrants in Spain. Links with undocumented migration and the labour market. In A. Kraler, E. Kofman, M. Kohli, \& C. Schmoll (Eds.), Gender, Generations and the family in international migration (pp. 143166). Amsterdam: Amsterdam University Press.

Jandl, M. (2004). The estimation of illegal migration in Europe. Studi Emigrazione/Migration Studies, 41(153), 141-155.

Kaag, M. (2008). Mouride transnational livelihoods at the margins of a European society: The case of residence Prealpino, Brescia, Italy. Journal of Ethnic \& Migration Studies, 34(2), 271-285.

Kossoudji, S. A., \& Cobb-Clark, D. A. (2000). IRCA's impact on the occupational concentration and mobility of newly-legalized Mexican men. Journal of Population Economics, 13(1), 81-98.

Kraler, A. (2009). Regularisation: A misguided option or part and parcel of a comprehensive policy response to irregular migration? (Vol. 24). Vienna: IMPCD.

Lessault, D., \& Beauchemin, C. (2009a). Ni invasion, ni exode. Regards statistiques sur les migrations d'Afrique subsaharienne. Revue Européenne des Migrations Internationales, 25(1), 163-194.

Lochak, D. (1997). Les politiques de l'immigration au prisme de la législation sur les étrangers. In D. Fassin, A. Morice, \& C. Quiminal (Eds.), Les lois de l'inhospitabilité: les politiques de l'immigration à l'épreuve des sans-papiers, Cahiers libres (pp. 29-45). Paris: La Découverte.

Marot, N. (1995). L'évolution des accords franco-africains. Plein droit, 29-30, 96-99.

Massey, D. S. (2007). Categorically unequal: The American stratification system. New York: Russell Sage Foundation.

Massey, D. S., \& Capoferro, C. (2004). Measuring undocumented migration. International Migration Review, 38(3), 1075-1102.

Massey, D. S., \& Espinosa, K. E. (1997). What's driving Mexico-U.S. migration? A theoretical, empirical, and policy analysis. The American Journal of Sociology, 102(4), 939-999.

Massey, D. S., Arango, J., Hugo, G., Kouaouci, A., Pellegrino, A., \& Edward Taylor, J. (1998). Worlds in motion: Understanding international migration at the end of the millennium. Oxford: Clarendon Press.

Massey, D. S., Durand, J., \& Malone, N. J. (2002). Beyond smoke and mirrors: Mexican immigration in an era of economic integration. New York: Russell Sage Foundation.

Massey, D. S., Durand, J., \& Pren, K. A. (2016). Why border enforcement backfired. American Journal of Sociology, 121(5), 1557-1600.

Menjívar, C. (2006). Liminal legality: Salvadoran and guatemalan immigrants' lives in the United States. American Journal of Sociology, 111(4), 999-1037.

Mezger, C., \& González-Ferrer, A. (2013). The impol database: A new tool to measure immigration policies in France, Italy and Spain since the 1960s (Vol. 34). Paris: INED.

Passel, J. S., \& D'Vera Cohn, S. W. (2011). Unauthorized immigrant population: National and state trends, 2010. Washington, D.C: Pew Hispanic Center.

Pastore, F., Monzini, P., \& Sciortino, G. (2006). Schengen's soft underbelly? Irregular migration and human smuggling across land and sea borders to Italy. International Migration, 44(4), 95-119. 
Phillips, J. A., \& Massey, D. S. (1999). The new labor market: Immigrants and wages after IRCA. Demography, 36(2), 233-246.

Portes, A. (2010b). Migration and social change: Some conceptual reflections. Journal of Ethnic and Migration Studies, 36(10), 1537.

Portes, A., \& Rumbaut, R. (2001). Legacies: The story of the immigrant second generation. Berkeley: University of California Press.

Portes, A., \& Rumbaut, R. (2006). Immigrant America: A portrait (3rd ed., rev.expanded, and update). Berkeley: University of California Press.

Reyneri, E. (1998). The role of the underground economy in irregular migration to Italy: Cause or effect? Journal of Ethnic and Migration Studies, 24(2), 313.

Riccio, B. (2008). West African transnationalisms compared: Ghanaians and Senegalese in Italy. Journal of Ethnic \& Migration Studies, 34(2), 217-234.

Ruhs, M., \& Anderson, B. (2010). Semi-compliance and illegality in migrant labour markets: An analysis of migrants, employers and the state in the UK. Population, Space and Place, 16(3), 195-211.

Schuster, L. (2005). The continuing mobility of migrants in Italy: Shifting between places and statuses. Journal of Ethnic and Migration Studies, 31(4), 757-774.

Sciortino, G. (1999). Planning in the dark: The evolution of Italian immigration control. In G. Brochmann \& T. Hammar (Eds.), Mechanisms of immigration control: A comparative analysis of European regulation policies (pp. 233-260). Oxford: Berg.

Sciortino, G. (2004). Between phantoms and necessary evils. Some critical points in the study of irregular migrations to Western Europe. In A. Böcker, B. de Hart, \& I. Michalowski (Eds.), IMIS-beiträge: Migration and the regulation of social integration. Osnabrück: Institut für Migrationsforschung und Interkulturelle Studien (IMIS).

Singer, A., \& Massey, D. S. (1998). The social process of undocumented border crossing among Mexican migrants. International Migration Review, 32(3), 561-592.

Spire, A. (2005). Etrangers à la carte: L'administration de l'immigration en France (1945-1975). Paris: Grasset.

Timera, M., \& Garnier, J. (2010). Les Africains En France: Vieillissement et Transformation d'une Migration. Hommes \& Migrations, 1286-1287, 24-35.

Triandafyllidou, A. (2010a). Irregular migration in Europe in the 21st Century. In A. Triandafyllidou (Ed.), Irregular Migration in Europe: Myths and Realities (pp. 1-21). Surrey: Ashgate Publishing, Ltd.

Triandafyllidou, A. (Ed.). (2010b). Irregular migration in Europe: Myths and realities. Surrey: Ashgate Publishing, Ltd.

van Nieuwenhuyze, I. (2008). Getting by in Europe's urban labour markets: Senegambian migrants' strategies for survival, Documentation and Mobility. Amsterdam: Amsterdam University Press.

Vollmer, B. A. (2011). Policy discourses on irregular migration in the EU - Number games and political games. European Journal of Migration and Law, 13(3), 317-339.

Wihtol de Wenden, C. (2010). Irregular migration in France. In A. Triandafyllidou (Ed.), Irregular

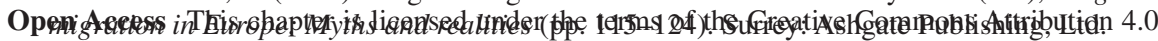
International License (http://creativecommons.org/licenses/by/4.0/), which permits use, sharing, adaptation, distribution and reproduction in any medium or format, as long as you give appropriate credit to the original author(s) and the source, provide a link to the Creative Commons licence and indicate if changes were made.

The images or other third party material in this chapter are included in the chapter's Creative Commons licence, unless indicated otherwise in a credit line to the material. If material is not included in the chapter's Creative Commons licence and your intended use is not permitted by statutory regulation or exceeds the permitted use, you will need to obtain permission directly from the copyright holder.

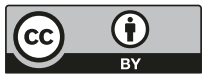

